\title{
PÜSKÜRTMELİ KURUTMA VE DONDURARAK KURUTMA YÖNTEMLERINIIN TEMELLERİ VE BU YÖNTEMLER İLE GIDA ATIKLARINDAN TOZ ÜRÜNLERIN ÜRETİMİ
}

Elif Ezgi Özdemir, Ahmet Görgüç, Esra Gençdağ, Fatih Mehmet Yılmaz*

Aydın Adnan Menderes Üniversitesi, Mühendislik Fakültesi, Gıda Mühendisliği Bölümü, Aydın, Türkiye

Geliş / Received: 18.01.2021; Kabul / Accepted: 16.03.2021; Online bask1 / Published online: 08.04.2021

Özdemir, E.E., Görgüç, A., Gençdağ, E., Yılmaz, F.M. (2021). Püskürtmeli kurutma ve dondurarak kurutma yöntemlerinin temelleri ve bu yöntemler ile gıda atıklarından toz ürünlerin üretimi. GIDA (2021) 46(3) 583-607 doi: 10.15237/gida. GD21009.

Özdemir, E.E., Görgüc, A., Gençdăg, E., Yılmaz, F.M. (2021). Püskürtmeli kurutma ve dondurarak kurutma yöntemlerinin temelleri ve bu yöntemler ile gıda atıklarndan toz ürünlerin üretimi. GID A (2021) 46(3) 583-607 doi: 10.15237/gida. GD21009.

\section{ÖZ}

Bu derleme makalede gıda atıkları ve/veya yan ürünlerinden gıda bileşenlerinin özütlenerek geri kazanımının ardından püskürtmeli ve dondurarak kurutma yöntemleri ile toz formda ürün üretimine yönelik çalışmalar ele alınmıştır. Gıda atıklarından özütlenen fenolik maddeler, vitaminler, renk maddeleri, aroma maddeleri, proteinler ve lifler gibi bileşiklerin hem dış etkenlere karşı dayanımlanın artırmak hem de gida formülasyonlarında kullanımını kolaylaştırmak için özütler kurutularak toz forma dönüştürülmektedir. Püskürtmeli ve dondurarak kurutucu sistem bileşenlerinin, çalışma prensiplerinin ve işlemlerde etkili faktörlerin de değerlendirildiği bu makalede özellikle son ylllarda gerçekleştirilen, her iki yöntemin bir arada kullanıldığı ve karşılaştırıldığı çalışmalar ele alınmıştr. Püskürtmeli kurutma ve dondurarak kurutma işlemlerinin ve kurutma yardımcı maddelerinin elde edilen toz ürünlerin verim, higroskopisite, nem içeriği, yapışkanlık, renk, çözünürlük, camsı geçiş sıcaklığı, yığın yoğunluğu, mikroyapı, elektron mikroskobu altndaki görünüm, antioksidan kapasite, antosiyanin ve toplam karotenoit içeriğgi gibi özellikleri üzerinde etkili oldukları anlaşılmaktadır.

Anahtar kelimeler: Toz gida ürünleri, camsı geçiş sıcaklığı, toz ürün üretimi, fonksiyonel toz ürünler, attk değerlendirme

\section{PRINCIPLES OF SPRAY DRYING AND FREEZE DRYING TECHNIQUES AND THEIR USE IN POWDER PRODUCTION FROM FOOD WASTES}

\begin{abstract}
In this review article, literature studies on the production of powder products by spray and freeze drying methods after the extraction of food components from food waste and/or by-products are discussed. The extracts are dried and converted into powder form in order to increase the stability of compounds extracted from food wastes, such as phenolic compounds, vitamins, coloring and flavoring agents, proteins, fibers, and to ease their use in food formulations. In this article, spray and freeze dryer system components, working principles and effective factors in processes are evaluated,
\end{abstract}

\footnotetext{
"Yazışmalardan sorumlu yazar / Corresponding author

๑1 fatih.yilmaz@adu.edu.tr

(D): (+90) 2562137503

国: (+90) 2562136686
}

Elif Ezgi Özdemir; ORCID no: 0000-0003-2800-9376

Ahmet Görgüç; ORCID no: 0000-0003-3018-4595

Esra Gençdağ; ORCID no: 0000-0002-4510-0940

Fatih Mehmet Yılmaz; ORCID no: 0000-0002-1370-1231 
and especially recent studies evaluating both methods are discussed. It is clear that the spray drying and freeze drying processes and drying auxiliaries are effective on powder properties such as the yield, hygroscopicity, moisture content, adhesiveness, color, solubility, glass transition temperature, bulk density, microstructure, appearance under electron microscope, antioxidant capacity, anthocyanin and total carotenoid contents.

Keywords: Powder food products, glass transition temperature, production of powder product, functional powder products, waste valorization

\section{GİRIŞ}

Gıda atıkları, gıda yaşam döngüsünün tüm aşamalarında, yani tarımsal üretim, endüstriyel üretim, işleme ve dağıtum sırasında açığa çıkmaktadır (Mirabella vd., 2014). Buna karşın birçok gida atığının insan sağlığı üzerinde faydaları olduğu bilinen önemli bileşiklerin kaynağı olduğu da iyi bilinmektedir (Bataglion vd., 2015). Özellikle bitki bazlı gidalar lif, antioksidanlar ve diğer fitokimyasal maddeler (fenolik asitler, flavonoitler vb.) açısından zengin ürünler olarak ilgi çekmektedir (Neacsua vd., 2015). Bitki kaynaklı yan ürünlerden/atıklardan özütlenen steroller, tokoferoller, karotenoitler, terpenler ve polifenoller gibi fitokimyasallar, önemli ölçüde antioksidan kapasiteye sahiptirler. Bu nedenle, bu tür atıklardan izole edilen bileşenler, fonksiyonel g1da formülasyonlarında doğal antioksidanlar olarak kullanılabilmekte ve raf ömrünü uzatmak için gıda ürünlerinde katkı maddesi olarak birçok alanda değerlendirilmektedir (Kalogeropoulos vd., 2012). Bu bağlamda bu bileşiklerin geri dönüştürülmesi önem kazanmaktadır. Vitaminler, probiyotikler, mineraller, polifenoller, omega-3yağ asitleri ve fitosteroller gibi bileşikler oksijene, 1şığa, yüksek sıcaklığa ve suya oldukça duyarlı olabilmekte; bu faktörlere bağlı olarak da gida ürünlerinin raf ömrü ve biyoyararlanımı sinırlanmaktadır (Champagne ve Fustier, 2007; Dordević vd., 2015). Kurutma işleminin önemi de burada ortaya çıkmaktadır. Gıda atıklarından ekstraksiyon sonrası toz ürün üretimine yönelik uygulanan genel işlemler Şekil 1'de özetlenmiştir.

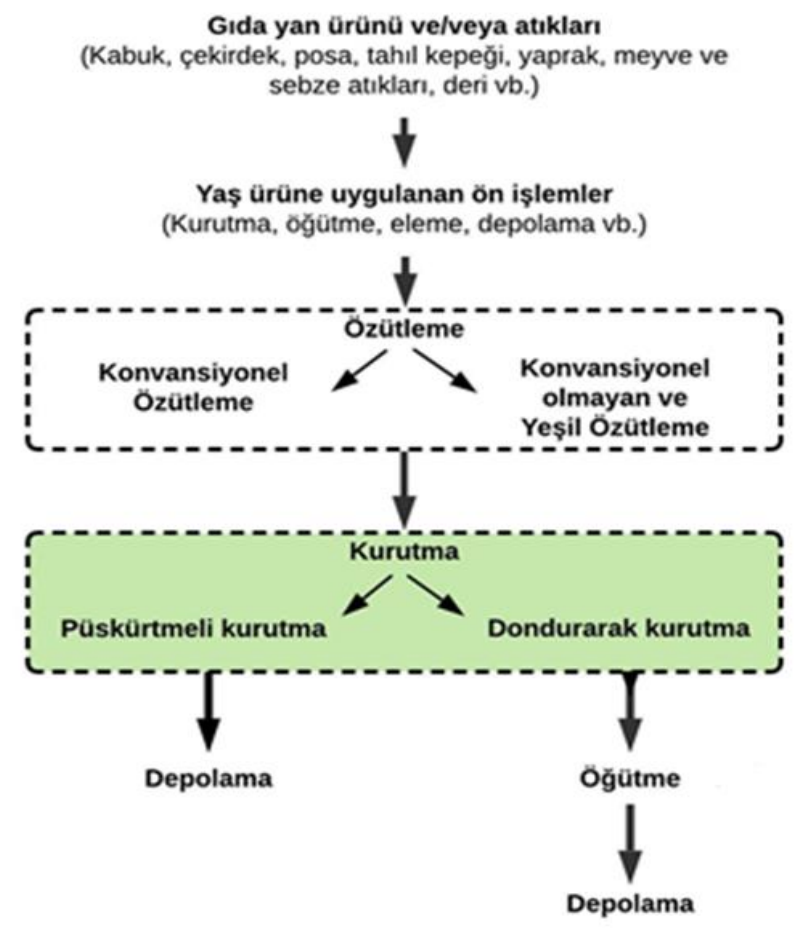

Şekil 1. Gıda atıklarından farklı maddelerin özütlenmesi ve toz ürün üretimi 
Püskürtmeli kurutma işlemi operasyon kolaylı̆g ve maliyet etkinliği sağlaması nedeniyle (Botrel vd., 2014) sıvı bir çözeltiyi kuru parçacıklara (toz g1da ve aglomerat) dönüştürmede yaygın olarak kullanılmaktadır (Shishir ve Chen, 2017). Dondurarak kurutma (liyofilizasyon) ise buzun süblimleşmesine dayanan bir dehidrasyon işlemi olarak tanımlanmaktadır (Marques ve Freire, 2005). Düşük sıcaklık ve basınç kombinasyonu şeklinde uygulanan bu işlem sayesinde nihai üründe renk ve lezzetin çok iyi derecede korunumunun sağlandığı, hızlı su penetrasyonuna ve rehidrasyon yoluyla tazeye yakın özelliklerin geri kazanılmasına olanak tanıdığı (Ceballos vd., 2012) ifade edilmektedir. Burada en önemli nokta kurutma yönteminin gidanın özelliklerine uygun şekilde seçilmesidir. Uygun kurutma yöntemi seçiminin önemi kurutma işlemi sonrasında elde edilen ürün kalitesinin en üst düzeyde tutulması, üretilen toz ürünün rehidrasyon özelliklerinin iyileştirmesi ve işlem parametrelerinin optimize edilmesi gibi durumlarda ortaya çımaktadır (Morgan vd., 2006).

$\mathrm{Bu}$ çalışsmada, püskürtmeli ve dondurarak kurutma yöntemleri, gıda atıklarından özütlenen farklı bileşenlerin kurutma yoluyla geri kazanımı, kurutma işlem parametrelerinin son ürün üzerindeki etkileri ve oluşabilecek olumsuzlukları en aza indirgemek amaciyla uygulanan işlemler ele alınmıştır. Okuyucuların, bu çalışmada sunulan literatür bulguları ile püskürtmeli ve dondurarak kurutma yöntemleri ve bu yöntemler kullanılarak g1da atıklarından toz ürün üretimi konuları hakkında bilgi edinmeleri amaçlanmıştır.

\section{GIDA ATIKLARI VE ATIKLARDA BULUNAN BIYYOAKTIF MADDELER}

Gida atıkları genellikle gida hammaddelerinin hasat edilmesi, işlenmesi veya nakliyesi sırasında açığa çıkan, sıvı veya katı formdaki organik kalıntılardır. $\mathrm{Bu}$ maddeler üretim sürecinden istenmeyen materyaller olarak uzaklaştırılmaktadırlar. Gıda işleme endüstrisinin her yil sadece Avrupa Birliği'nde 100 milyon ton civarında gida atığ1 ve yan ürünü ürettiği bilinmektedir. $\mathrm{Bu}$ durum, toplam hasadın üçte birinden fazlasının hasat ve gıda işleme sırasında kaybolduğu veya atıldığ1 anlamına gelmektedir.
Gıda üretim, işleme, dağıtım ve depolama gibi gıda tedarik zincirinin farklı aşamaları sırasında en fazla oranda gıda atığ1 açığa çıkan gida prosesleri incelendiğinde içecek endüstrisinin \%26'lık kayıp ile ilk sirada olduğu, bunu $\% 21.3$ ile süt ve dondurma endüstrisinin, \%14.8'lik kayıpla ise meyve ve sebze endüstrisinin takip ettiği araştırmacılar tarafindan bildirilmiştir (Arshadi vd., 2016).

Genel olarak gida atıkları karbonhidratlar (nişasta, selüloz, hemiselüloz veya lignin), proteinler, lipitler, organik asitler ve daha küçük inorganik kısımlardan oluşan heterojen bir yapıya sahiptirler. $\mathrm{Bu}$ atıklar günümüzde çoğunlukla hayvan yemi ve kompost olarak geri dönüştürülmekte, kalan atıklar ise yakılarak imha edilmektedir. Bu durum da sera gazı olarak karbondioksitten 23 kat daha fazla oranda ve iklim değişikliğine önemli ölçüde etkisi bulunan metan gazı emisyonuna neden olmaktadır (Lin vd., 2013). Sanayileşme ve küresel nüfus artışı ile birlikte gıda endüstrisi tarafından üretilen atık maddelerin bertarafi ciddi çevresel sorunlar yaratmaktadır. İşleme tesislerindeki çevresel atıklar yenilikçi işleme yöntemleri kullanılarak yeniden kullanım yoluyla önemli ölçüde azaltılabilme potansiyeline sahiptir. Günümüzde atık maddeleri biyoyakitlara, gida bileşenlerine ve diğer katma değerli biyoürünlere dönüştürmeyi amaçlayan, atıkların ve yan ürünlerin bir kaynak haline geldiği çeşitli süreçler geliştirilmektedir (Makris, 2007).

Gıdaların işlenmesi sonucu oluşan yan ürünler ve/veya gida attkları aynı zamanda polisakkaritler, lezzet bileşikleri, enzimler, polifenoller, uçucu yağlar, pigmentler, besinsel lifler, proteinler (Zhu vd., 2016), antioksidanlar ve renklendiriciler gibi değerli işlevsel bileşiklerin eldesinde kullanilabilmektedir. Bu kaynaklar bol ve ucuz, uygun teknolojik ve/veya beslenme özelliklerine sahip bileşikler için önemli kaynaklar olduklarından ticari açıdan değerli ürünlerin üretiminde kullanılabilirler (Luque ve Clark, 2013).

Son y1llarda polifenoller, karotenoitler, peptitler, steroller veya çoklu doymamış yağ asitleri gibi doğal biyoaktiviteye sahip bileşikleri içeren 
fonksiyonel gidalara olan talep gün geçtikçe artmakta, bu bağlamda fonksiyonel ürünlerin geliştirilmesi için gida endüstrisi tarafindan sürdürülebilir ve yeni fonksiyonel bileşenler talep edilmektedir (Herrero vd., 2015). Bu sebeple, gida sanayisinde birçok gıdanın işlenmesinde ve üretiminde oluşan bitkisel ve hayvansal yan ürün ve/veya atıkların farklı amaçlarla kullanımı gün geçtikçe artmaktadır. Özellikle bitkisel gidalar, işleme sonucunda çok miktarda yan ürün üretmesi nedeniyle ilgi odağı haline gelmiştir. Son yıllarda yapılan araştırmalar bu yan ürünlerin birçoğunun potansiyel olarak değerli bileşenlerin kaynağ1 olabileceğini de ortaya koymuştur (Yılmaz vd., 2021). Örneğin, buğdayın öğütülmesi, pirinç kabuklarının ayrıştırılması veya yulafın öğütülmesi sonucu protein ve besinsel lifler açısından zengin olan kepek veya saman gibi yan ürünler üretildiği ve bu atıklardan antioksidan peptit (Zaky vd., 2020), protein (Chen vd., 2021) ve çözünebilir diyet lifi (Yan vd., 2019) gibi bileşiklerin elde edildiği bildirilmiştir. Bununla birlikte, bitkisel yan ürünlerden ve/veya atıklardan elde edilen fenoller ve karotenoitler, gida endüstrisinde doğal gida veya içecekler için fonksiyonel bileşenler olarak kullanilabilirler (Oreopoulou ve Tzia, 2007). Örnek olarak, palm yağı üretimi sonucu açığa ç1kan küspeden (Tsouko vd., 2019), kestane yapraklarından (Munekata vd., 2016) ve zeytinyağ1 üretimi sırasında oluşan pirina, zeytin yaprağ ve karasudan fenolik bileşiklerin (Venturi vd., 2017) veya zeytin sirkesi (De Leonardis vd., 2018) eldesine yönelik çalışmalar mevcuttur. Şekerleme ürünlerinde jelleştirici olarak veya et ürünlerinde yağ yerine kullanılabilen pektinin (Galanakis vd., 2010) ticari olarak üretimi için ana kaynak narenciye kabuklarıdır (Putnik vd., 2017). Kakao kabuğu (Chan ve Choo, 2013), nar kabuklar1 (Pereira vd., 2016) ve muz kabuğu (Oliveira vd., 2016) da değerlendirilen diğer bitkisel gida atıklarındandır. Suda çözünmeyen lifler de bağırsak fonksiyonlarının düzenlenmesini sağlayan, fonksiyonel gıda üretiminde kullanılan bileşiklerdir (Rodríguez vd., 2006). Ginseng bitkisinin atıklarından (Hua vd., 2019) çözünmeyen lif, domates kabuklarından (Gu vd., 2020) çözünür lif; portakal kabuğundan ise flavonoitler (Pereira vd., 2017), uçucu yağlar (Hashtjin ve Abbasi, 2015) ve karotenoitlerin
(Murador vd., 2019) geri kazanımını ele alan literatür bulguları mevcuttur.

\section{TOZ ÜRÜNLER VE TOZ (KURU) ÜRÜN ÜRETİM AVANTAJLARI}

Tüketim davranışlarındaki son gelişmeler, özellikle gıda ve tüketim alanlarının çeşitlenmesi, gıda şirketlerini formülasyon programlarını geliştirmeye itmektedir. Yeni bir ürünün geliştirilmesi sürecinde gıdanın korunması, taşınması, depolanması, tartılması ve işlenmesi kolay işlevsel bileşenler kullanmayı da beraberinde getirmektedir (Cuq vd., 2011). Gidalann toz forma dönüştürülmesi de bu noktada önem kazanmaktadır. Toz gıda, küçük ve gevşek parçacıklar şeklindeki kuru bir katı gıda ürünü olarak ifade edilebilir. Bu ürünler sağlı için temel besinleri sağlamasının ötesinde spesifik ve faydalı bir fizyolojik etki sağlamak üzere tasarlanmışsa o zaman fonksiyonel toz ürün olarak adlandırılmaktadır. Taze veya sulu/yaş bir katıdan toz g1da üretimiyle ilgili ana işlemler, kurutma ve/veya boyut küçültme şeklinde özetlenebilmektedir (Chronakis vd., 2004). G1da işleme sırasındaki uygulamalarda ve ürün formülasyonlarında kolaylık sağlamak, duyusal çekiciliği artırmak, ürünün besin içeriğinin iyileştirilmesi gibi sebeplerden ötürü birçok gidanın toz formda kullanımı tercih edilmektedir (Dhanalakshmi vd., 2011). Bu bağlamda tüm gida ürünlerinin yaklaşı \% $\%$ 'inin kuru (toz, susuz parçacıklar vb.) forma dönüştürülebileceği ifade edilmektedir (Burgain vd., 2017). Bu ürünlere yumurta tozları, süt tozları, jelatin tozları, g1da katk1 maddeleri, vitaminler, meyve ve sebze tozları, baharatlar, renklendirici maddeler örnek olarak verilebilir. Gıda ürünlerinden veya atıklarından elde edilen bu tozlar kullanım ve saklama kolaylığı sağlaması açısından gıda endüstrisinde geniş kullanım alanı bulmaktadır (Cuq vd., 2011).

Tozların, bileşimini ve işlevselliğini daha karmaşık hale getiren bileşenlerin kompleks bir karışımı olduğunu belirtmek gerekmektedir. Gidalardaki makro bileşenlerin (su, karbonhidrat, protein ve yağlar) fiziksel durumundaki herhangi bir değişiklik, gıda tozunun minör bileşenlerinin (vitamin, fenolik bileşikler vb.) kimyasal 
özelliklerini de etkilemektedir. Örneğin gıdanın su içeriğinin yüksek olması toz üründe yapışkanlık ve katılaşma gibi istenmeyen fiziksel değişikliklere yol açarak ürünün depolama stabilitesinin azalmasina neden olabilmektedir. Benzer şekilde, lipit ve protein oksidasyonu ile enzimatik olmayan esmerleşme reaksiyonları istenmeyen karakteristik tatların oluşumuna, renk bozulmasına ve besin değeri kaybına yol açmaktadır (Burgain vd., 2017). Dolasıyla, kurutma yönteminin gidanın özelliklerine uygun şekilde seçilmesi önem arz etmektedir. Uygun kurutma işlemi seçiminin önemi kurutma işlemi sonrasında elde edilen ürün kalitesinin en üst düzeyde tutulması, üretilen toz ürünün rehidrasyon özelliklerinin iyileştirmesi ve işlem parametrelerinin optimize edilmesi gibi konularda ortaya çıkmaktadır (Morgan vd., 2006). Böylece depolama, kanş̧tırma ve rehidrasyon gibi işlemlerin etkinliğini artırmak, toz ürünlerin davranışını belirlemek ve kontrol altına almak da kolaylaşmaktadır (Ermiş ve Karasu, 2019).

\section{PÜSKÜRTMELİ KURUTMA}

Püskürtmeli kurutma, yüksek su içeriğine sahip pompalanabilir sivilarin kurutulmasinda ölçeklenebilirliği, sürekli çalışması ve standart kalite özellikleri nedeniyle yaygın olarak kullanılan yöntemlerin başında gelmektedir (Yerlikaya ve Şen Arslan, 2019). Ayrıca, bu kurutma yöntemi kısa uygulama süresi ve kolay kontrol edilebilir çalışma koşullarına sahiptir. Püskürtmeli kurutma işlemi çeşitli ürün gruplarını işleme potansiyelinin yanında renk, lezzet ve besin değeri gibi özellikleri yüksek ölçüde korunabilen ürünler için ideal bir kurutma sistemi olarak öne çıkmaktadır (Haque vd., 2015). Tüm bunlara ek olarak, ekonomik olması, toz ürünlerde partikül yoğunluğu, yığın yoğunluğu ve kristallenme derecesi gibi parametreler üzerinde kontrol kolaylığ1 sağlamas1 bu kurutma sisteminin avantajlarını artırmaktadır (Haggag ve Faheem, 2015).

Püskürtmeli kurutma işlemi, sıcak hava veya inert gaz gibi bir akışkan yardımıyla sulu veya organik çözeltilerin atomizasyonu ve ardından kurutulmasını içermektedir (Haque vd., 2015). Sistemdeki akışkan, kurutma ortamına küçük damlaciklar halinde püskürtülmekte ve bu damlaciklar sıcak gaz/hava ortamına doğru hareket ederek küçük parçacıklar şeklinde kurumaktadır (Nuzzo vd., 2015). Besleme bileşimine ve işlem koşullarına bağlı olarak elde edilen nihai parçacıklar çok ince nano boyutlu tozlar (210-280 nm), mikron boyutunda ince tozlar $(10-50 \mu \mathrm{m})$ veya aglomeratlar $(3 \mathrm{~mm}$ 'ye kadar) olabilmektedir (Gharsallaoui vd., 2007).

Püskürtmeli kurutma ile üretilen tozların kalitesi, sisteme beslenen çözeltinin özelliklerine (viskozite, akış hızı vb.), kurutma havasına (basınç/sıcaklık ve akış hızı), sıcak hava ile kurutma odasındaki damlaciklar arasındaki temas oranı veya mesafeye, kullanılan atomizer türüne (eş zamanlı veya ters akım) ve hızına bağlı olarak değişmektedir (Shishir ve Chen, 2017). Buna ek olarak, kurutulmuş ürünün özellikleri ise beslenen ürünün fiziksel ve kimyasal özelliklerinin yanında kurutucu sistem tasarımına ve işlem parametrelerine bağlı olarak belirlenmektedir (Keshani vd., 2015). Dolayisıyla, püskürtmeli kurutulmuş tozların kalitesi, akış özelliği, sıkıştırılabilirlik, kütle yoğunluğu, dağılabilirlik, çözünürlük, ürün kompozisyonu ve püskürtmeli kurutma işlem parametrelerine bağlı olarak değişmektedir (Haque vd., 2015). Tipik bir püskürtmeli kurutucu sisteminin şematik gösterimi Şekil 2'de verilmiştir.

Püskürtmeli kurutma işlemi temel olarak (I) Sisteme beslenecek sivinin ince damlaciklar halinde atomize edilmesi, (II) Damlacikların sicak hava ile temas1, (III) Atomize edilen damlaciklarin kurutulması ve (IV) Kurutulmuş damlacıkların nemli havadan ayrilmas1 olmak üzere dört adımdan oluşmaktadır (Malamatari vd., 2020).

\section{Atomizasyon}

Atomizasyonun temel amacı daha geniş yüzey alanı ve daha verimli bir 1sı ve kütle aktarımı sağlayarak beslenen sıvı ürünün kurutma yüzey alanını artırmaktır. Atomizasyon işlemi için döner atomizerler, hidrolik nozullar, pnömatik nozullar ve ultrasonik nozullar gibi sistemler kullanılmaktadır (Cal ve Sollohub, 2010). Püskürtmeli kurutma işleminde atomizer tasarımı, atomizasyon basinc1 ve atomizasyon hiz1 gibi parametreler toz ürünün fiziksel (boyut, şekil vb.) özelliklerini önemli derecede etkilemektedir 
(Shishir ve Chen, 2017). Kurutma sirasinda atomize edilmiş damlacıklar ve sıcak hava bir kurutma bölmesinde etkileşime girerek damlacık sıcaklığını artırmaktadır. Bu durum ise küçük su damlacıklarının buharlaşma hızının artmasını sağlamaktadır. Bu süreçte damlacık yüzeyinde kuru bir tabaka oluşurken, damlacıktaki nem içeriği de kritik noktaya ulaşmaktadır. Sonuçta elde edilen toz parçaciklar hammaddenin yapısına ve kurutma koşullarına bağlı olarak pürüzsüz veya pürüzlü; küresel veya oval şekilli olabilmektedir (Caparino vd., 2012). Örneğin, atomizasyonu sağlamak için uygulanan enerji ne kadar yüksek olursa damlacıklar/parçacıklar o kadar küçük boyutta olacaklardır (Gharsallaoui vd., 2007). Chegini ve Ghobadian (2005) yaptıkları çalışmada daha yüksek atomizer hızında daha küçük damlacıkların oluştuğunu ve bununla birlikte temas yüzeyinin artmasiyla daha fazla nemin buharlaştırılabildiğini göstermişlerdir. Bu sayede de küçük parçacık boyutu ve hızlı kuruma sağlandığını, sonuç olarak damlackkların üzerinde kabuk oluşumunun önlendiği bildirilmiştir. Yüksek atomizer basınçlarında toz ürünün parçacık boyutu ve nem içeriği azalırken katı yüzdesi ve yığın yoğunluğunun arttığ1 yapilan çalısmalarda rapor edilmiştir (Tee vd., 2012).

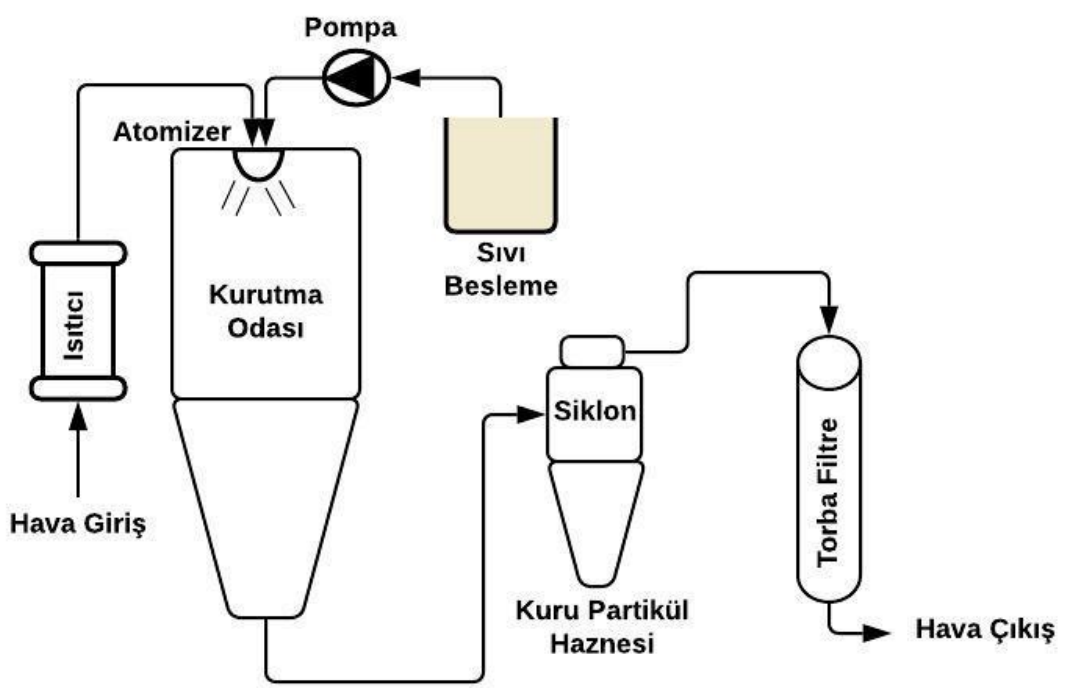

Şekil 2. Püskürtmeli kurutma sisteminin şematik gösterimi

\section{Damlacik-Sicak Hava Teması}

Damlacık-hava teması beslenen ürünün atomizasyonundan hemen sonra kurutma odasında gerçekleşmektedir. Bu aşamada, havanın termal enerjisi buharlaşma için kullanılmakta ve soğumuş hava kurumuş partikülleri kurutma sistemi boyunca pnömatik olarak taşımaktadır (Phisut, 2012). Bu süreç atomize edilmiş damlacıkların suyun buharlaşmasını kolaylaştıran ısıtıllmış hava ile karşılaşması şeklinde özetlenebilir. Püskürtmeli kurutma işleminde sıcak hava geniş bir hacimde kurutma odasında dolaşmaktadır. Dolayısıyla bu kurutma sisteminin termal etkinliği oldukça düşüktür. Ayrıca, damlackk boyutunun kontrolünün de sinırlı olmas1 geniş boyutlu parçacık dağılımına ve bazen de düzensiz mikro yapıya neden olabilmektedir (Dalmoro vd., 2012). Bu sebeple son ürünün yüksek verimle toplanabilmesi için tozun kurutma odas1 duvarlarına temas etmeden önce yeterince kurumuş olması gerekmektedir (Haque vd., 2015). Duvara parçacık yapışma durumu genellikle meyve suyu gibi şeker ve organik asit içeriği yüksek ürünlerde görülmektedir. Yapışma sorunu ise esas olarak sükroz, glikoz ve fruktoz gibi düşük molekül ağırlıklı şekerler ile organik asitlerin 
düşük cams1 geçiş sicaklığından $\left(T_{g}\right)$ kaynaklanmaktadır (Goula, 2017). Yüzey toz birikmesi veya yapışması aynı zamanda kurumuş parçacıklar ve kurutma odası iç yüzeyi arasındaki kaçınılmaz temastan kaynaklanmaktadır. Birçok üründe, tortular belirli bir kalınlığa kadar biriktikten sonra düşmektedir (Goula ve Adamopoulos, 2010). Buna karşın eğer materyal kuruyana kadar ekipman duvarlarına temas etmezse püskürtmeli kurutma işlemi süresince daha az yapişma ve korozyon gerçekleşeceği belirtilmektedir (Chegini vd., 2008).

\section{Atomize Damlacıkların}

\section{Kurutulması/Buharlaştırılması}

Kurutma işleminde sisteme beslenen damlacıklar, sicak hava ile temas ettiği anda suyun buharlaşması ile kurumakta ve bu sırada kuru toz parçacıkları oluşmaktadır. Daha genel bir ifadeyle, kurutma işlemi ilk olarak kurutma odasinda damlacıkların hava ile temasıyla başlamaktadır. Isı transferi ise suyun damlaciklardan buharlaştığ sslak termometre sıcaklığına ulaşana kadar artmaya devam etmektedir. Kurutma işleminde suyun buharlaşması sabit sıcaklıkta ve su buharı kısmi basıncında gerçekleşmektedir. Son olarak damlacık yüzeyinde kuru bir kabuk oluştuktan sonra kurutma oranı azalmakta ve difüzyon hizına bağımlı hale gelmektedir. Kurutma havası sıcaklı̆g1 ile partikül sıcaklığ1 eşitlendiğinde ise kurutma işlemi tamamlanmaktadır (Gharsallaoui vd., 2007). Kurutulmuş parçacıklar, kurutma odasından çıktıkları anda kurutucu çıkış sıcaklığına yakın durumdadırlar. Kurutma işlemi süresince her damlacığın yüzeyinden hızlı buharlaşma meydana gelmektedir. Sicak hava, kurutucuya beslenen ürünün damlaciklarına temas ettiği anda büyük çoğunlukla kuruma işlemi de gerçekleşmiş olacaktır. Bu hızlı buharlaşma aynı zamanda beslenen ürün tamamen kuruyana kadar damlacıkların yüksek sıcaklığa maruz kalmasını önlemektedir (Shishir ve Chen, 2017).

Püskürtmeli kurutma işlemindeki son adım ise kurutulmuş parçacıkların nemli havadan ayrılarak bir haznede toplanmasıdır. Bu esnada üründen uzaklaştırılan nem ise genellikle siklon ve kurutma odasının dişına yerleştirilen bir torba filtre ile kurutma ortamından uzaklaştırılmaktadır.
Taneciklerin kurutma ortamından ayrilmasinın etkinliği taneciklerin yoğunluğuna, boyutuna ve bunların siklon içindeki çökelme hızına bağlı olarak değişmektedir (Haque vd., 2015). Ürün geri kazanımı esas olarak toz ürün toplama verimliliği ile belirlenmektedir. Bir püskürtmeli kurutma sistemindeki ürün kaybı çoğunlukla püskürtülmüş damlacikların ve kuru tozun aparatın duvarına tutunmasından ve siklonun ince parçaciklar toplamadaki etkinliğinin yetersiz olmasından kaynaklanmaktadır (Goula vd., 2004).

\section{Püskürtmeli Kurutma Parametrelerinin Toz Ürün Özelliklerine Etkisi}

Toz ürünlerin fiziksel özellikleri arasında parçacık (partikül) şekli, yoğunluk, gözeneklilik, yüzey özellikleri, parçacık çap1 ve boyutunu saymak mümkündür. Kurutulmuş toz ürünlerin fizikokimyasal özellikleri, kurutma işlemi süreçlerini ve işlevselliği optimize etmek ve maliyetleri azaltmak açısından önem arz etmektedir (Barbosa-Cánovas ve Juliano, 2005). Örneğin, partikül boyutunun azalması veya partikül yüzey alanındaki artş, neme karşı daha yüksek bir afiniteye ya da kurutma işlemi sırasında aglomerasyona (kümeleşme) neden olabilmektedir (Chindapan vd., 2018). Toz ürünün yoğunluk bilgisi ise işleme, paketleme, depolama ve dağııım koşullarının ayarlanmasında malzeme bilimi çalışmaları ve endüstriyel süreçler için önemli avantajlar sağlamaktadır. Buna ek olarak, yığın yoğunluğu değeri ögütme veya kurutma ile elde edilen nihai ürünü karakterize etmek için kullanılmaktadır (Barbosa-Cánovas ve Juliano, 2005). Ayadi vd. (2008), püskürtmeli kurutma işlem koşullarının kurutulmuş yumurta ak1 ve bütün yumurta tozlarının özellikleri üzerindeki etkisini incelemişlerdir. Yazarlar, kurutma esnasındaki besleme akış hızına ve giriş havası sicaklığına bağlı olarak spesifik köpüklenme, jelleşme ve emülsifiye edici özelliklere sahip toz ürün elde edildiğini bildirmişlerdir. Dolayısıyla, son üründe istenen özellikleri elde etmek için püskürtmeli kurutma işlemi sırasında farklı parametreler kontrol edilerek yüksek kalitede tozlar elde edilebilmektedir. $\mathrm{Bu}$ sayede yapısskanlık, higroskopi özellikleri ve düşük çözünürlük gibi 
baz1 yapisal dezavantajların da önüne geçilebilmektedir (Vidović vd., 2014).

\section{Hava Giriş/Kurutma S1cakliğı}

Kurutma sıcaklığı, püskürtmeli kurutulmuş tozun fizikokimyasal özelliklerini etkileyen önemli faktörlerden birisidir (Shishir ve Chen, 2017). Daha yüksek hava giriş/kurutma sıcaklığının kurutma hızını artırarak toz ürün veriminde artış sağladığı; bunun yanında artan kurutma hızı ile birlikte toz ürünün nihai nem içeriği ile kütle yoğunluğunun da önemli ölçüde etkilendiğini gösteren çalışmalar mevcuttur (Jafari vd., 2017). Diğer yandan yüksek kurutma sıcakliklarının kullanılması, toz üründe yer alan 1siya hassas değerli bileşenleri yok etme ve cams1 geçiş sıcaklığının aşılması suretiyle yapışkanlığı artırma riski de taşımaktadır (Looi vd., 2019). Muzaffer ve Kumar (2015), demirhindi özünden püskürtmeli kurutma sistemi ile toz ürün elde ettikleri çalışmalarında hava giriş sıcaklığındaki artışla birlikte meydana gelen 1s1 ve kütle aktarımındaki artışın, verimliliği artırdığını tespit etmişlerdir. Yüksek kurutma sıcaklığı, kurutma odasına daha fazla 1sı transferi sağlaması nedeniyle kurutma hızını arttırarak kurutulmuş ürünün nem içeriğini azaltmaktadır. Ayrıca toz ürünün kalıntı nem içeriğinin azalması sebebiyle ortalama sslanabilirlik süresinde bir artışa, yani 1slanabilirlik özelliklerinde azalmaya neden olmaktadır (Chegini ve Ghobadian, 2005). Benzer şekilde, Sun vd. (2020) püskürtmeli kurutma sıcaklığının mikroenkapsüle karvakrol tozlarının fiziksel özellikleri üzerindeki etkilerini incelemiş ve nem içeriği ile ylğın yoğunluğunun kurutma sıcaklığındaki artışla azaldığı sonucuna varmışlardır. Jafari vd. (2017) ise hava giriş sicaklığının nar suyu tozunun fonksiyonel özellikleri üzerindeki etkisini incelemiş ve giriş hava sıcaklığının artmasıyla birlikte protein çözünürlüğünün azaldığını tespit etmişlerdir. Püskürtmeli kurutulan ürünün parçacık boyutu, kurutma giriş sıcaklığına bağlı olarak değişebilmektedir. Kurutma sıcakllğındaki artış, kürelerin düzgün şekilde büzülmesine izin vermeden büyük partikül oluşumuna neden olan hızlı bir su buharlaşmasına neden olmaktadır. Büyük partiküller genellikle daha gözenekli bir yapıya sahip olduğundan partikül yoğunluğunda azalma eğilimi gözlenmektedir (Fazaeli vd., 2012).

\section{Hava Çıkış Sicakliğı}

Toz parçacıklarının nemli havadan ayrllip siklonun dibine birakıldığı andaki siklon sıcaklığ1, hava çıkış sıcaklığı olarak kabul edilmektedir. Hava çıkış sıcaklığı, toz halindeki ürünlerin kurutma sürecini ve fizikokimyasal özelliklerini kontrol etmede kullanilan önemli bir parametredir (Shishir ve Chen, 2017). Püskürtmeli kurutma işleminde kurutma çıkış sıcaklığının daima düşük tutulması ve kurutmanın mümkün olduğunca hızlı gerçekleştirilmesi, sıcaklığa duyarlı proteinler ve peptitler açısından ürünün bozulmasını/denatürasyonunu önlemek adına önem arz etmektedir (Prinn vd., 2002). Yüksek çıkış sıcaklığının nem içeriği ve proses verimini artırdığ 1 bazı çalışmalarda rapor edilmiştir (Tontul ve Topuz, 2017). Hava çıkıs sıcaklığının toz özellikleri üzerinde önemli etkileri vardır. Maa vd. (1997), düşük hava çıkış sıcaklığının toz partiküllerin küreselliğini artırdığını belirtmiştir. Yazarlar aynıca hava çıkış sıcaklığının besleme akış hızı ve atomize hava akış hızının artsşına bağlı olarak azaldığını tespit etmişlerdir. Bu durum hava çıkış sıcaklığının diğer kurutma parametrelerinden etkilendiği gerçeğini desteklemektedir. Hava giriş ve çıkış sıcaklıkları arasındaki fark ne kadar fazla ise sicaklık ve buhar basinc1 gradyanları da o derece yüksek olacak; bu durum ise buharlaşma ve parçacık oluşumunun daha hızlı gerçekleşmesini sağlayacaktır (Haque vd., 2015).

\section{Besleme Akş Hizı}

Besleme akış hızı, püskürtmeli kurutma düzeneğinin kapasitesi de dikkate alınarak bir sıvı materyalin toz ürün kalitesi ve verim ele alınarak kurutulmasında önemli parametrelerden birisi olarak kabul edilmektedir (Miller ve Gil, 2012). Muzaffer ve Kumar (2015), püskürtmeli kurutma işleminin yüksek besleme hızında gerçekleştirildiğinde meydana gelen yavaş isı ve kütle aktarımının işlem verimi üzerinde olumsuz bir etki gösterdiğini belirtmişlerdir. Aynı çalışmada, besleme akış hızındaki artış ve hava giriş sıcaklığındaki azalmanın, toz örneklerin nem içeriğini doğrusal yönde etkileyen bir değişken 
olan higroskopik özelliğini azalttığ1 tespit edilmiştir.

Besleme akış hızı temel olarak atomizer hızı ile doğru orantılı olarak değişmektedir. Yüksek akış hızına sahip besleme, aynı miktarda nemi damlacıklardan buharlaştırmak için daha fazla enerjiye ihtiyaç duymakta, dolayısıyla daha yavaş 1s1 ve kütle transfer hizına neden olarak damlacıkların kurumasını zorlaştırmaktadır (Shishir ve Chen, 2017). Benzer şekilde Kurozawa vd. (2009), yaptkkları çalısmada tavuk eti tozlarındaki nem içeriğinin, daha yüksek besleme hızının damlaciklar ile kurutma havası arasındaki temas süresini azaltması nedeniyle düşük verimli bir 1s1 transferine ve daha düşük oranda su buharlaşmasına neden olduğunu belirtmişlerdir. Başka bir çalışmada ise yüksek hava giriş sıcaklı̆̆ı, düşük besleme akış hızı, yüksek atomizasyon basıncı ve yüksek hava akış hızında toz ürün nem içeriğinin daha düşük olduğu tespit edilmiştir (Telang ve Thorat, 2010). Bununla birlikte, yüksek hava akış hızında ve düşük besleme akış hızında daha yüksek ürün verimine ulaşıldığ1 belirlenmiştir. Diğer yandan Souza vd. (2009), kurutucu sisteme beslenen çözelti yoğunluğunun besleme akış hızı ve atomizasyon hızı ile ters orantılı olduğunu, atomizer hızı ile besleme akış hızının ise domates tozunun parçacık boyutu üzerinde önemli bir etki gösterdiğini belirtmişlerdir.

\section{Hava Akş Hizı}

Kurutma havası akış hızı, buharlaşma için gereken süreyi etkilemesi sebebiyle püskürtmeli kurutma işleminde önemli bir faktördür. Kurutma havas1 akış hızı suyun buharlaşma hızını etkilemektedir. Düşük hava akış hızı damlacıkların kuruma süresini artırırken yüksek kuruma süresi daha fazla miktarda suyun buharlaşmasına neden olmaktadır (Goula vd., 2004). Yüksek hava akış hızı daha kısa kurutma süresi sağlamasına karşın yetersiz oranda bir kurutma sağlaması nedeniyle nihai üründe yüksek nem içeriğine neden olabilmektedir (Shishir ve Chen, 2017).

Püskürtmeli kurutma işlemi esnasında iç duvarlarda biriken ürünler iki kategoriye ayrllmaktadır: Duvara çarpmadan önce yeterince kuru olmayan damlacikların neden olduğu yarı sslak tortular ve kurutma sicaklığında ürünün doğasından kaynaklı yapışkan tortular (Goula ve Adamopoulos, 2010). İlk kategorideki tortu oluşumu aynı zamanda işlem veriminin azalmasına da neden olan hava akış hızının azaltılması ile gerçekleşmektedir. Benzer şekilde, yüksek hava akış hızı damlacık çaplarında azalmaya neden olmakta ve küçük parçacık boyutlu damlaciklar kurutma odasinda nem içeriğinin çok daha düşük olduğu kısımlarda duvara çarpma eğilimi göstermektedirler (Fazaeli vd., 2012).

\section{Toz Ürün Verimi}

Püskürtmeli kurutma işleminin verimliliği, buharlaştırmada kullanılan isının toplam is girdisine oranı olarak tanımlanmaktadır (Goula ve Adamopoulos, 2003). Fazaeli vd. (2012)'nin çalışma verilerine göre yüksek hava giriş sıcaklığ proses veriminde ve çözünürlükte artış sağlarken yığıı yoğunluğu, nem içeriği ve su aktivitesi değerinde azalma meydana getirmektedir. Buna karşın, hava akış hızı artışının kurutma verimi ve kütle yoğunluğu üzerinde olumlu; çözünürlük, nem içeriği ve su aktivitesi değeri üzerinde ise olumsuz bir etkiye sahip olduğu belirtilmiştir.

Kurutma işlemi etkinliği adına önemli bir gösterge olan toz ürün verimliliği ise kurutma sonrası elde edilen toplam toz madde kütlesinin başlangıçta sisteme beslenen çözeltide yer alan toplam kuru madde kütlesine oranı olarak tanımlanmaktadır. Nihai toz ürünün verimi ve fiziksel özellikleri, besleme konsantrasyonu, besleme akış hızı, atomizasyon hızı/basıncı ve kurutma sıcaklığı gibi çeşitli faktörlerden etkilenmektedir (Tontul ve Topuz, 2017). Düşük ürün verimi ise temel olarak özellikle şekerler gibi bazı gida bileşenlerinin yapışkanlık özelliklerinden ileri gelmektedir (Can Karaca vd., 2016). Örnek olarak León-Martínez vd. (2010), yaptıkları bir çalışmada en düşük toz ürün veriminin yüksek toz nem içeriği ve düşük hava çıkış sıcaklığına neden olan yüksek besleme akış hızı ve düşük giriş sıcaklığı koşullanında elde edildiğini bildirmişlerdir. Bu kurutma koşulları altında, kurutma odasının duvarında yapışmaların görüldüğü de ayrıca vurgulanmıştır. Aynı çalışma sonuçlarına göre verim üzerinde besleme akış 
hızının atomizer hızından daha büyük bir etkiye sahip olduğu, bununla birlikte sabit besleme hızında atomizasyon hızı arttıkça verimin de arttğ tespit edilmiştir. Başarnlı bir püskürtmeli kurutma işleminde ürün veriminin $\% 50$ 'den yüksek olması gerektiği bildirilmektedir (Elez Garofulić vd., 2016).

\section{Püskürtmeli Kurutma İşleminde Dikkat Edilmesi Gereken Noktalar}

Püskürtmeli kurutma işleminde dikkat edilmesi gereken noktaların başında ürünün camsı geçiş sıcaklığı gelmektedir. Camsı geçiş sıcaklığı sert, katı ve amorf bir maddenin yumuşak, kauçuk benzeri ve sıv1 bir faza dönüştüğü sıcaklıktır. Camsı geçiş sıcaklığının saptanması için yaygın olarak kullanılan ölçüm yöntemi ise camsı geçiş sıcaklığ1 aralığında meydana gelen, cam ve kauçuksu durumlar arasındaki şekilsiz bileşenin 1s1 akışındaki değişikliği tespit eden diferansiyel taramalı kalorimetre (DSC) cihazıdır (Fazaeli vd., 2012).

Püskürtmeli kurutulmuş gıdalar yapışkan ve yapsşkan olmayan olmak üzere iki gruba ayrilabilmektedir. Yağsız süt, maltodekstrin, zamksı maddeler ve proteinlere ait çözeltilerden yapışkan olmayan; meyve-sebze suları ve bal gibi şeker ve asit açısından zengin gidalardan ise yapışkan karakterde toz ürünler elde edilmektedir. Şeker ve asitçe zengin malzemelerin yapışkan toz davranışı genel olarak fruktoz $\left(-5^{\circ} \mathrm{C}\right)$, glikoz $(32$ $\left.{ }^{\circ} \mathrm{C}\right)$, sükroz $\left(62^{\circ} \mathrm{C}\right)$ gibi şekerlerin düşük cams 1 geçiş sıcaklığından ve sitrik, malik ve tartarik asit gibi organik asitlerin varlığından kaynaklanmaktadır (Adhikari vd., 2003). Bu bileşenler püskürtmeli kurutma işlemi esnasında kurutucu duvarlarına yapışma ve toz yerine macun benzeri bir yap1 oluşturma eğilimi göstermektedirler (Goula ve Adamopoulos, 2010). Bir ürünün camsı geçiş sıcaklığını ise sıcaklık, nem ve ürün bileşimi olmak üzere üç temel faktör etkilemektedir (Intipunya ve Bhandari, 2010).

Düşük cams1 geçiş sıcakliğ1 püskürtmeli kurutma işlemi sırasında istenmeyen fiziksel değissikliklere (yapışma, kabuk bağlama, topaklanma vb.) neden olabilmektedir. Aynı zamanda, üründe renk ve aroma değişikliklerinin yanında bazı kimyasal değişiklikler de meydana gelebilmektedir. $\mathrm{Bu}$ sebeple, bu tarz istenmeyen durumların önüne geçmek için parçacıkların yüzey sıcaklığının kurutulacak ürün camsı geçiş sıcaklığının en az 20 ${ }^{\circ} \mathrm{C}$ altında olması önerilmektedir (Fazaeli vd., 2012). Ürün nem içeriği de camsı geçiş sıcaklığının düşürülmesinde önemli bir rol oynamaktadır. Toz ürünlerin birçoğu $\% 5$ ten düşük nem içeriğine sahip olmasına rağmen nem içeriğindeki $\% 1$ gibi küçük bir artışın camsı geçiş sıcaklığını önemli ölçüde azaltabildiği vurgulanmaktadır (Intipunya ve Bhandari, 2010). Bu sebeple beslenen ürünlerin camsı geçiş sıcaklığını yükseltmek için farklı teknolojilerin kullanımı tavsiye edilmektedir. Bu yöntemler kurutulacak ürünün yüksek nişasta, şeker veya yağ içeriğine sahip olduğu durumlarda ürünün verimi ve kalitesini düşüren yapışkanlık ve çökelme gibi durumları önlemek amacıyla da kullanılmaktadır.

\section{DONDURARAK KURUTMA}

Liyofilizasyon olarak da adlandirilan dondurarak kurutma işlemi, dondurulacak gidanın kurutma işleminden önce dondurulması ve ardından gıdadaki suyun düşük basınç altında doğrudan süblime edilmesine dayanan bir kurutma yöntemidir (Nireesha vd., 2013). Başarıllı bir liyofilizasyon işlemi gerçekleştirmek için kurutma odasındaki basıncın en fazla $40 \mathrm{~Pa}$ mutlak basınçta tutulması gerekmektedir (Toledo, 2007). Düşük sıcaklık ve basıncın kombinasyonu şeklinde uygulanan bu işlem sayesinde renk ve lezzetin iyi derecede korunması sağlanırken kurutulmuş ürünün süngerimsi yapısı hızlı su penetrasyonuna ve rehidrasyon yoluyla tazeye yakın özelliklerin geri kazanılmasına olanak tanımaktadır (Ceballos vd., 2012).

Günümüzde dondurarak kurutma, g1da maddeleri ve farmasötikler (aş1, protein, peptit, kolloidal taşıyıcı vb.) dahil olmak üzere yüksek katma değerli ürünlerin kurutulması ve stabilitesinin artırlmasında önemli bir endüstriyel işlem haline gelmiştir (Kumar vd., 2011). Buna ek olarak, dondurarak kurutma işleminin gıda ürünlerinin kurutulmasinda tercih edilmesinin en önemli sebepleri arasında raf ömrü uzun ve gelișmiș rehidrasyon özelliklerine sahip yüksek kaliteli 
ürünler elde edilmesine olanak tanımas1 gösterilmektedir (Schössler vd., 2012). Gıdalar yapısında doğal olarak vitamin ve protein gibi isıya duyarlı bileşenler içerdiğinden bu tür biyomateryallerin kurutulması termal ayrışma, oksidasyon veya enzimatik esmerleşmeye sebep olabilmektedir (Marques ve Freire, 2005). Bu nedenle bu ürünlerin kurutulmasi esnasinda dondurarak kurutma gibi özel tekniklerin kullanımı ek avantajlar sağlamaktadır (Menon vd., 2020). Liyofilizasyon işlemi yüksek yatırım maliyeti ve enerji tüketimi nedeniyle özellikle katma değeri yüksek ürünlerin kurutulmasında kullanılmaktadır (Schössler vd., 2012).

Dondurarak kurutma işlemi temel olarak (I) Malzemenin dondurulması, (II) Süblimleştirme ile dondurulmuş suyun uzaklaştırılması (birincil kurutma) ve (III) Ürünün nem desorpsiyonunu teşvik etmek için daha fazla 1situlması (ikincil kurutma) olmak üzere üç temel aşamadan oluşmaktadır (Searles vd., 2017).

\section{Dondurma (Katılaştırma) Adımı}

Ürünün dondurulmas1, dondurarak kurutma işleminin ilk adımıdır. Dondurma sırasında dondurulacak malzemeden elde edilen süspansiyon ilk olarak suyun faz diyagramında (Şekil 3) bulunan üçlü noktasının $\left(0.01{ }^{\circ} \mathrm{C}=\right.$ $273.16 \mathrm{~K}$ ) altındaki sıcaklığa soğutulmaktadır. Bu adımda serbest su olarak adlandırılan suyun büyük bir kısmı buz olarak kristalleşirken geri kalan kısım konsantre çözeltide bağlı su olarak bulunmaktadır (Pisano vd., 2011).

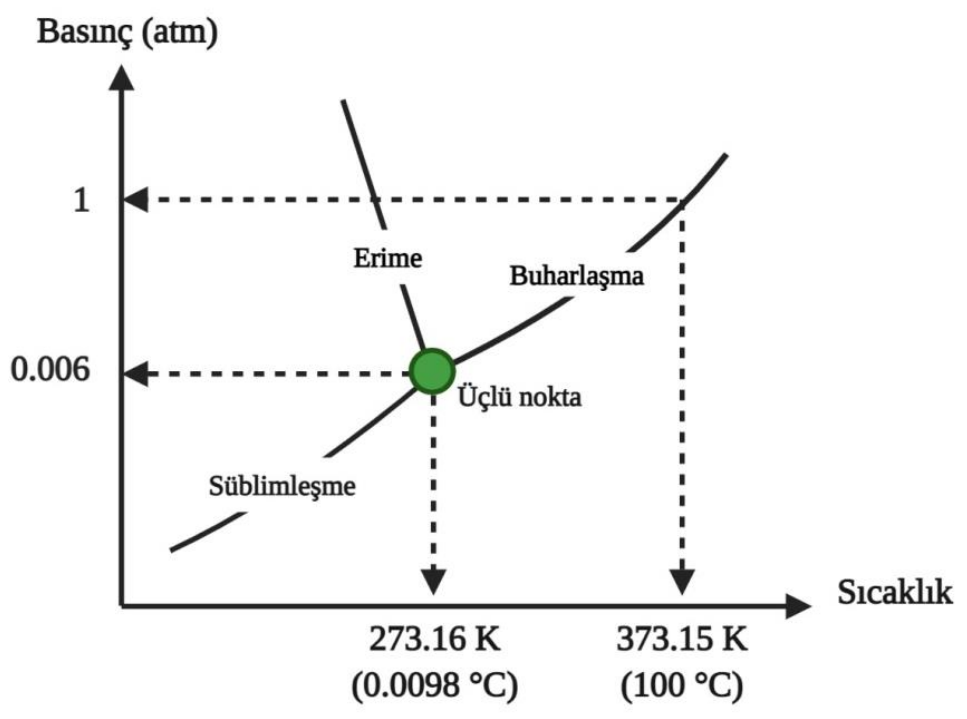

Şekil 3. Saf suyun faz diyagramı

Dondurma işlemi sırasında oluşan buz kristallerinin homojen dağılımı, etkili bir liyofilizasyon işleminin en önemli göstergelerindendir (Ratti, 2013). Dondurma koşullarının seçimi, dondurma işleminin verimliliğini optimize etmek ve örneklerin mikro yapısını korumak açısından büyük önem arz etmektedir (Delgado ve Rubiolo, 2005). İşlem koşulları aynı zamanda buz kristallerinin şeklini ve boyutunu, dolayısıyla kurutulmuş tabakadan buhar akışına karşı oluşan direnci belirlemede de etkilidir (Marques ve Freire, 2005). Örnek olarak, büyük buz kristalleri elde etmek ve böylelikle süblimleşme adımını kısaltmak için ürün özelliklerine bağlı olarak tavlama ve soğutma gibi işlemler uygulanarak donma hızı veya doğrudan çekirdeklenme sıcaklığı (buz kristallerinin çözelti içerisinde ilk olarak oluştuğu sıcaklık) kontrol 
edilebilmektedir (Ratti, 2013). Düşük donma hızı hücrelerin aynı anda dehidrasyonunu ve harici sıvıların dondurulmasını sağlamakta, böylelikle büyük buz kristallerinin oluşumunu önleyerek süblimleşme aşamasında buhar akısını artırmaktadır. Hücrelere büyük miktarda çözünmüş madde geçişi ve su kaybı nedeniyle hücre zarlarında yırtılmalar meydana gelebilmektedir. Buna karşın, yükssek dondurma hızında oluşan küçük buz kristalleri hücre zarlarına hasar verilmemesini sağlamakta ancak süblimasyon sırasında su buharı akısı azaldığından kurutma için gereken süre artmaktadır (Cao vd., 2018). Kahve gibi bazı örneklerde gözenekli matriks yapisinda daha hizlı bir kurutma sağlanabildiğinden büyük buz kristalleri tercih edilmektedir. Çoğu gıda örneğinde ise büyük buz kristalleri hücre duvarlarına hasar vermekte ve rehidre edilmiş ürünün zayıf bir dokuya sahip olmasina neden olabilmektedir (Pisano vd., 2011).

\section{Birincil Kurutma (Buz Süblimasyonu) ve İkincil Kurutma}

Tipik bir liyofilizatör büyük bir valf vasıtasıyla bir kondenser odasına bağlanan sicaklık kontrollü raflar içeren bir kurutma odasından oluşmaktadır. Kondenser haznesi ise çok düşük sıcaklıklarda ($50{ }^{\circ} \mathrm{C}^{\prime}$ den düşük) muhafaza edilebilen bir dizi plaka veya bobin içermektedir (Pikal, 2002). Birincil kurutma aşaması dondurulmuş üründen buzun süblime edilmesini içermektedir. $\mathrm{Bu}$ işlemde öncelikle 1s1, dondurulmuş çözeltiye tepsi ve flakon yoluyla aktarilarak süblimasyon cephesine iletilmektedir. Süblimleşen buz ve oluşan su buharı, ürünün kurutulmuş yüzeyinden kondensere aktarilmakta ve su buharr kondenser üzerinde yoğuşmaktadır. Süblimasyon adımının sonunda gözenekli bir yapı oluşmaktadır. Oluşan bu gözenekler, donmuş üründe buz kristallerinin kapladığı alanlara karşılık gelmektedir (Gaidhani vd., 2015). İkincil kurutma sirasinda ise dondurulan üründen emilen suyun uzaklaştırılması işlemi gerçekleşmektedir. Bu aşamada uzaklaşan su, dondurma sırasında buz olarak ayrilmayan ve süblimleşmeyen suyu içermektedir (Kawasaki vd., 2019).

\section{Dondurarak Kurutma İşleminin Avantajları, Dezavantajları ve Diğer Kurutma Yöntemleriyle Karşılaştırılması}

Kurutma işleminin süresi ve sıcaklığı, kurutulmuş gıdaların kalitesini etkileyen en önemli faktörlerdendir. Herhangi bir gıda ürünü için en iyi kurutma yöntemi hammadde özelliklerine, arzu edilen son ürün kalitesine ve ekonomik faktörlere bağlı olarak değişebilmektedir (Moses vd., 2014). Dondurarak kurutma işleminde istenen dehidrasyon ve rehidrasyon oranların sağlayabilmek için soğutma hızının da optimize edilmesi gerekmektedir (Assegehegn vd., 2019). Dondurarak kurutma işlemi sırasında dikkate alınması gereken temel faktör, ürün kalitesini bozabileceğinden belirli sınırların altında kalması gereken ancak yavaş ve maliyetli bir işlemi önlemek için yeterince süblimasyon sağlayacak kadar da yüksek bir sıcaklık değerinin kullanılmasidir. Dondurarak kurutma sirasinda ürün sıcaklığ1 raf sicaklı̆̆1 ve hazne basincinın ayarlanmas1 ile kontrol edilebilmektedir. Raf sıcaklığını sabit tutan hazne basıncındaki artış, süblimasyon verimini arttrırken ürün sicaklığını istenmeyen seviyelere yükseltebilmektedir. Süblimasyon oranını üründe fazla ssınmaya neden olmadan artırmak için bir diğer seçenek de raf sıcaklığındaki artışla birlikte ortam basıncını azaltmaktır (Ratti, 2013).

Her kurutma tekniğinin kendine özgü avantaj ve dezavantajlar1 mevcuttur. Dondurarak kurutma işlemi besinsel değerleri iyi derecede korunmuş, rehidrasyon, doku ve renk gibi parametrelerin taze ürüne yakıı olduğu ürünler elde edilmesine olanak sağlamaktadır (Voda vd., 2012). Bununla birlikte, dondurarak kurutma ürünlerin dondurulmas1, dondurulmuş numunelerin süblimasyonunu indüklemek için 1sıtılması ve dehidrasyon odasının toplam basıncının düşürülmesi nedeniyle oldukça yüksek enerji gereksinimi olan bir işlemdir (Donsì vd., 2001). Dolayısıyla, günümüzde dondurarak kurutma işleminin gida endüstrisinde kullanımı bazı meyve, sebze ve et ürünleri gibi yüksek katma değerli ürün grupları ile sinırlı durumdadır (Schössler vd., 2012). Dondurarak kurutma yöntemi, gida işlemede geleneksel kurutma işlemlerinde uygulanan yüksek sıcaklık nedeniyle zarar görebilen organoleptik özellikleri korumak 
veya depolama ve nakliye için daha uygun hale getirmek için kullanılabilir. İşlem çok düşük bir sıcaklıkta gerçekleştirildiği için dondurarak kurutulmuş gidalarda taze ürünlere ait aroma ve doku korunmakta ve gözenekli yapı oluşmasına izin verilmektedir (Pisano vd., 2011). Diğer yandan bu arzu edilen ürün özelliklerini elde etmek için uzun işlem süreleri ve yüksek maliyetler gereklidir. Dondurarak kurutma işlemleri birkaç saatten birkaç güne kadar uzayabilen bir sürede gerçekleşmekte, bu durum da enerji maliyetini artırmaktadır (Schössler vd., 2012). Dondurarak kurutma işlemi ile toz ürünlerin besinsel ve aroma özellikleri diğer bazı kurutma yöntemlerine kıyasla daha iyi oranda korunabilse de uygulamanin yüksek maliyeti, bu teknolojinin endüstride kullanımını sinırlandırmaktadır (Duan vd., 2016). Aynı zamanda, kurutma raflarındaki yüzey sıcaklığının homojen olmaması aynı partideki ürün sıcaklıklarında farkliılılara neden olarak eşit kaliteye sahip ürün elde edilmesini zorlaştırabilmektedir (Fonte vd., 2016). Dondurarak kurutulmuş ürünler işlem sonunda ögütülerek toz haline getirilmelidir. Yüksek derecede higroskopik ürünler ortamdaki nemden etkilenme eğilimi göstereceğinden öğütme işlemi sirasinda serbest akan bir toz elde etmek için olabildiğince kuru ortam şartlarının sağlanması gerekmektedir. Kurutulmuş örneğin \%2-3'ten yüksek nem içeriğinin olması değirmenlerin tıkanmasina neden olabilmektedir (BarbosaCánovas vd., 2005).

Dondurarak kurutma, nihai toz ürünün kalitesi açısından çoğunlukla en iyi dehidrasyon yöntemi olarak kabul edildiğinden genellikle diğer kurutma yöntemlerinin performansını test etmek için referans olarak kullanılmaktadır. Özellikle gıda çözeltilerinin püskürtmeli kurutucuda kurutulmasinda, dondurarak kurutma ile karşılaştırmasının yapıldığı çok sayıda çalışma mevcuttur (Ratti, 2013). Püskürtmeli kurutma işlemi hızlı kurutma, yüksek verim ve sürekli çalışma gibi çeşitli avantajlar sağlayan bir kurutma yöntemidir (Ziaee vd., 2019). Püskürtmeli kurutulmuş ürünler toz, granül veya aglomerat formunda elde edilebilmektedir (Nindo ve Tang, 2007). Bununla birlikte püskürtmeli kurutma işlemi farklı partikül boyutu dağılımına sahip, nispeten serbest akışl1 ve muntazam küresel yapılı parçacıklar üretmeye imkân veren bir yöntemdir (Barbosa-Canovas vd., 2005). Buna karşın, ürün tipine bağlı olarak püskürtmeli kurutma işleminin dondurarak kurutmaya kiyasla renk ve aroma kaybı gibi bazı dezavantajları bulunmaktadır.

\section{PÜSKÜRTMELİ KURUTMA VE DONDURARAK KURUTMA YÖNTEMLERİ İLE GIDA ATIKLARINDAN ÖZÜTLENEN MADDELERINN TOZ FORMDA ÜRETİLMESİ}

Gıda endüstrisinde tahılların, meyve ve sebzelerin, yağlık tohumların ve et ürünlerinin işlenmesi esnasında veya sonrasında içeriğinde kıymetli bileşenlerin de olduğu yan ürünler ve çoğu zaman da atıklar ortaya çıkmaktadır. Bu atıkların bünyesinde yer alan aktif maddelerin geri kazanımı sağlanarak hem ekonomik hem de çevresel katkı sağlanmaktadır. Meyve ve sebzelerin posaları ve çekirdekleri, tahılların kabukları ve kepekleri, yağlık tohumların küspeleri ve balık işleme atıkları aktif biyolojik maddeleri önemli miktarda içermektedir (Oreopoulou ve Tzia, 2007). Bu maddeler arasinda yer alan polifenollerin, renk maddelerinin, prebiyotik liflerin, hidrokolloidlerin, yağ asitlerinin ve biyoaktif peptitlerin hem insan sağlığına hem de teknolojik olarak yeni ürünlerin formülasyonlarında faydalı etkileri olduğu vurgulanmaktadır (Herrero vd., 2015). Gida atıklarından ve/veya yan ürünlerinden bu maddelerin geri kazanıminda uygulanan en temel işlem özütlemedir (ekstraksiyon). Atık matriksi ve bu matrikste yer alan hedef bileşenin kimyasal niteliğine göre uygun çözücü ve yöntem ile yüksek verimlilikte geri kazanımının sağlanması birincil hedeftir (Luque ve Clark, 2013). Özütlemenin ardından genellikle çözücünün uzaklaştrrılması (süperkritik akışkan özütleme hariç) sağlanmakta ve konsantre özüt uygun ambalaj materyalinde tıp, eczacilık, gida, kozmetik, vb. alanlarda kullanılmak üzere tüketiciye veya ara sektörlere arz edilmektedir (Herrero vd., 2015). Bu özütlerin daha yüksek raf ömrü ve stabiliteye sahip olması ile formülasyonlarda kullanımlarının kolay olması arzulandığından toz forma dönüştürülmesi özellikle son yıllarda ele alınan başlı başına bir 
konu olmuştur. $\mathrm{Bu}$ amaçla gıda atıklarından üretilen özütler, püskürtmeli kurutma ve dondurarak kurutma yöntemleri ile toz forma dönüştürülmektedir. Her iki yöntemin temeline ve son toz üründeki genel etkilerine yukarıda detaylı değinilmesine rağmen, özütlerin polar - apolar özellikleri ile hidrofilik - hidrofobik niteliklerine göre bu yöntemlerden ne şekilde etkilenecekleri çoğu zaman öngörülememektedir (Yerlikaya ve Şen Arslan, 2019). Bu yüzden bu konuda gerçekleştirilen çalışmalarda her iki yöntemin bir arada ele alındığı ve karşılaşturma şeklinde toz ürünün fiziksel özellikleri ile diğer kimyasal ve biyokimyasal özelliklerinin sunulduğu görülmektedir (Chronakis vd., 2004). Dondurarak kurutma yöntemi; kurulum maliyeti, işlem süresi \& maliyeti ve işlem hacmi açılarından dezavantajlı gösterilmesine rağmen 1sıya duyarlı (thermolabile) bileşenlerin özellikle ilaç sanayisinde kullanılmak üzere en yüksek oranda korunumunun sağlanmasında tercih edilmektedir (Ratti, 2013). Püskürtmeli kurutma yöntemi, özütlerden toz ürün veya toz mikrokapsül üretiminde teknolojik olarak daha çok tercih edilmektedir (Vidović vd., 2014). Çalışmalarda, püskürtmeli kurutma işlem parametrelerinin optimizasyonunun son ürün özellikleri dikkate alınarak gerçekleştirilmesinin önemine dikkat çekilmektedir. Optimizasyonun ele alınmadığ1 çalışmalarda dondurarak kurutma yöntemi ile kıyaslamanın sağlıklı olmayacağı bir gerçektir. Zira püskürtmeli kurutma işleminde hava giriş sıcaklığ1 ve atomizasyon basınc1 gibi değisskenlerin farklılaşmasıyla verim, akabilirlik ve higroskopik özellikler oldukça etkilenebilmektedir (Muzaffer ve Kumar, 2015). Dolayisiyla optimizasyonun ele alınmadığı çalışmalarda son toz ürün özelliklerinin bu yöntemlerden doğrudan ne derece etkilendiği ile ilgili somut yorumlar yapmak güçtür. G1da atıklarından elde edilen hedef maddelerin biyokimyasal özellikleri göz önüne alınarak bir kurutma yönteminin seçimi toz ürün üretimi için büyük önem arz etmektedir. Kalite açısından, ürün mikroyapısının ve fonksiyonel bileşiklerin dehidrasyon (kurutma) yönteminin bir fonksiyonu olarak karşılaştırılmasına da son zamanlarda eğilim artmaktadır. Bu bağlamda g1da atıklarından hem püskürtmeli hem de dondurarak kurutma ile üretilen bileşiklerin son ürün özelliklerini değerlendiren karşılaştırmalı bazı çalışmalar Çizelge 1'de özet halinde sunulmuştur.

Çizelge 1. Gıda işleme sonucu oluşan atık ve/veya yan ürünlerden farklı materyallerin püskürtmeli ve dondurarak kurutma yöntemleri ile geri kazanımı için yapılmış bazı çalışmalar

\begin{tabular}{|c|c|c|c|c|c|}
\hline Hammadde & $\begin{array}{l}\text { Hedef } \\
\text { bileşik/ürün }\end{array}$ & Püskürtmeli kurutma & Dondurarak kurutma & Ortak özellikler/faydalar & Kaynak \\
\hline $\begin{array}{l}\text { Üzüm } \\
\text { kabuğu }\end{array}$ & Antosiyanin & $\begin{array}{l}\text { Toz mikrokapsüller daha } \\
\text { düşük ortalama çap }(0.56 \\
\mu \mathrm{m}) \text { ve daha yüksek } \\
\text { antosiyanin kapsülleme } \\
\text { verimi }(\sim \% 75) \text {; karanlikta } \\
\text { depolama sirasinda ise en } \\
\text { düşük bozunma sabiti } \\
(0.0207 \quad 1 / \mathrm{sa}) \text { ve en uzun } \\
\text { yarılanma ömrüne (33.47 sa) } \\
\text { sahiptir. Püskürtülerek } \\
\text { kurutulmuş mikrokapsüller } \\
\text { tüm analizlerde en yüksek } \\
\text { stabiliteye sahiptir. }\end{array}$ & $\begin{array}{l}\text { Dondurarak kurutulmuş } \\
\text { örnekler ortalama çap }(\sim 100 \\
\mu \mathrm{m}) \text {, antosiyanin kapsülleme } \\
\text { verimi }(\sim \% 71) \text {, bozunma } \\
\text { sabiti }(0.02551 / \mathrm{sa}) \text { ve } \\
\text { yarılanma ömrü }(27.14 \text { sa }) \\
\text { açısından püskürtmeli } \\
\text { kurutmaya kıyasla daha } \\
\text { düşük stabilite sağlamı̧tır. }\end{array}$ & & $\begin{array}{l}\text { Zang vd. } \\
(2020)\end{array}$ \\
\hline $\begin{array}{l}\text { Siyah pirinç } \\
\text { kepeği } \\
\text { (Oryza } \\
\text { sativa L.) }\end{array}$ & Antosiyanin & $\begin{array}{lr}\text { Hava giriş } & \text { s1caklığındaki } \\
\text { artışla birlikte } & \text { yığın } \\
\text { yoğunluğu ve } & \text { antosiyanin } \\
\text { tutulmasında } & \text { azalma } \\
\text { meydana } & \text { gelirken } \\
\text { dehidrasyon, } & \text { işlem } \\
\text { verimliliği, } & \text { çözünürlük, } \\
\text { dağ1labilirlik, akabilirlik ve } \\
\text { parçacık } & \text { yüzeyindeki } \\
\text { pürüzlülükte } & \text { artış } \\
\text { gözlenmiştir. } & \end{array}$ & $\begin{array}{l}\text { Dondurularak kurutulmuş } \\
\text { antosiyanin tozları ylğın } \\
\text { yoğunluğu, işlem verimliliği } \\
\text { ve antosiyanin hapsedilmesi } \\
\text { açısından daha üstün nitelik } \\
\text { sağlamıştır. }\end{array}$ & $\begin{array}{lr}\text { Kırılmış siyah } & \text { pirinç } \\
\text { unundan elde } & \text { edilen } \\
\text { maltodekstrin } & \text { kullanımı, } \\
\text { her iki } & \text { kurutma } \\
\text { yönteminde } & \text { de } \\
\text { antosiyanin } & \text { tozu } \\
\text { üretiminde } & \text { yüksek } \\
\text { verimlilik sağlamıştır. }\end{array}$ & $\begin{array}{l}\text { Laokuldilok } \\
\text { ve Kanhaa } \\
(2015)\end{array}$ \\
\hline
\end{tabular}


Çizelge 1. devam

\begin{tabular}{|c|c|c|c|c|c|}
\hline Hammadde & $\begin{array}{l}\text { Hedef } \\
\text { bileşik/ürün }\end{array}$ & Püskürtmeli kurutma & Dondurarak kurutma & Ortak özellikler/faydalar & Kaynak \\
\hline $\begin{array}{l}\text { Yildız } \\
\text { meyvesi } \\
\text { (Averrboa } \\
\text { carambola) } \\
\text { posas1 }\end{array}$ & $\begin{array}{l}\text { Fenolik } \\
\text { bileşikler }\end{array}$ & $\begin{array}{l}\text { Toz ürün daha yüksek "L" } \\
\text { değerine ve higroskopik } \\
\text { özelliğe sahiptir. Kaplama } \\
\text { materyalinde maltodekstrin } \\
\text { konsantrasyonunun } \\
\text { artmasıla kapsüllerin } \\
\text { higroskopikliğinde azalma } \\
\text { gözlenmiştir. Kurutulmuş } \\
\text { mikrokapsüllerin bazıları } \\
\text { küresel şekildeyken bazıları } \\
\text { düz görünüme sahiptir. }\end{array}$ & $\begin{array}{l}\text { En } \\
\text { mikroenkapsülasyon yüksek } \\
\text { verimliliği elde edilmiştir. } \\
\text { Öğütme sırasında tozlar, } \\
\text { serbest akış özelliği gösteren } \\
\text { amorf ve camsı bir yapıda } \\
\text { görünmüştür. Maltodekstrin } \\
\text { ile kaplanan örneklerin } \\
\text { parçacık boyutunda küçülme } \\
\text { ve kapsüllerde daha keskin } \\
\text { kenarlı yapılar meydana } \\
\text { gelmiştir. }\end{array}$ & $\begin{array}{l}\text { Özütleme işlemine ait } \\
\text { optimize edilmiş model } \\
\text { koşullarında }\left(40{ }^{\circ} \mathrm{C} \text { işlem }\right. \\
\text { s1caklığ1 ve } \% 65 \text { etanol } \\
\text { konsantrasyonu) üretilen } \\
\text { yıldız meyvesi posası } \\
\text { polifenol } \\
\text { mikroenkapsüllerinin, } \\
\text { farklı gida sistemlerinde } \\
\text { antioksidan özellikleri } \\
\text { artırmak amacıyla } \\
\text { kullanılabilir olduğu } \\
\text { belirlenmiştir. }\end{array}$ & $\begin{array}{l}\text { Saikia vd. } \\
(2015)\end{array}$ \\
\hline $\begin{array}{l}\text { Üzüm } \\
\text { (Vitis } \\
\text { labrusca var. } \\
\text { Bordo) } \\
\text { kabuğu }\end{array}$ & $\begin{array}{l}\text { Fenolik } \\
\text { bileşikler }\end{array}$ & $\begin{array}{l}\text { Örnekler daha düşük nem, } \\
\mathrm{a}_{\mathrm{w}} \text { ve parçacık boyutuna, } \\
\text { daha yüksek çözünürlüğe } \\
\text { sahiptir. Mikropartiküller } \\
\text { daha yüksek cams1 geçiş } \\
\text { sıcaklığ1 değerine sahip } \\
\text { olmuştur. Parçacıklar küresel } \\
\text { bir şekle sahiptir. En iyi } \\
\text { kapülleme } \% 5 \text { kismi } \\
\text { hidrolize guar gam ve } \% 5 \\
\text { polidekstroz ile sağlanmıştır. }\end{array}$ & $\begin{array}{l}\text { Parçaciklar düzensiz yapilar } \\
\text { ve daha az higroskopik } \\
\text { özellik sergilemiştir. }\end{array}$ & & $\begin{array}{l}\text { Kuck ve } \\
\text { Noreña } \\
(2016)\end{array}$ \\
\hline $\begin{array}{l}\text { Avokado } \\
\text { kabuğu }\end{array}$ & $\begin{array}{l}\text { Antioksidan } \\
\text { bileşikler }\end{array}$ & \begin{tabular}{lrr} 
Nisin ve & \multicolumn{2}{r}{ antioksidan } \\
avokado & kabuğu özütü \\
karışımı & koaservasyon \\
yöntemiyle & başarıyla \\
kapsüllenmiştir. Emülsiyon \\
haline getirilmiş kompleksler \\
sayesinde daha yüksek \\
mikroenkapsülasyon & verimi \\
elde edilmiştir.
\end{tabular} & $\begin{array}{l}\text { Emülsiyon haline getirilmiş } \\
\text { kompleksler ile daha yüksek } \\
\text { su aktivitesi ve nem değeri } \\
\text { elde edilmiştir. }\end{array}$ & & $\begin{array}{l}\text { Calderón- } \\
\text { Oliver vd. } \\
(2017)\end{array}$ \\
\hline $\begin{array}{l}\text { Așisız } \\
\text { yaban } \\
\text { mersini } \\
\text { posası }\end{array}$ & $\begin{array}{l}\text { Polifenol- } \\
\text { protein } \\
\text { kompleksi }\end{array}$ & 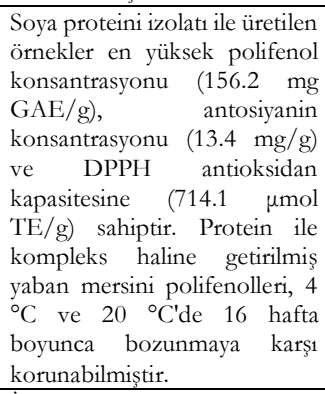 & $\begin{array}{l}\text { En düşük su aktivitesi değeri } \\
\text { nohut unu ile üretilen } \\
\text { örneklere aittir. }\end{array}$ & $\begin{array}{lr}\text { Toplam fenolik ve } \\
\text { antosiyanin } & \text { içerikleri } \\
\text { benzer } & \text { sonuçlar } \\
\text { sağlamıştır. } & \end{array}$ & $\begin{array}{l}\text { Correia vd. } \\
\text { (2017) }\end{array}$ \\
\hline $\begin{array}{l}\text { Kahve } \\
\text { telvesi }\end{array}$ & $\begin{array}{l}\text { Fenolik } \\
\text { bileşikler }\end{array}$ & $\begin{array}{l}\text { İkinci en yüksek fenolik } \\
\text { içerik } 1: 1 \quad(w / w) \text { oranında } \\
\text { maltodekstrin ve gam arabik } \\
\text { karışımı ile kapsüllenmiş } \\
\text { örneklerden elde edilmiştir. }\end{array}$ & $\begin{array}{l}\text { En iyi sonuçlar, fenolik } \\
\text { bileşiklerin maltodekstrin ile } \\
\text { kapsüllenmesi sonucu }(\% 62) \\
\text { elde edilmiş ve flavonoit geri } \\
\text { kazanım oranı } \% 73 \text { olarak } \\
\text { belirlenmiştir. } \\
\begin{array}{l}\text { öncesinde Kurutma } \\
\text { antioksidan kapasitenin } \% 73-\end{array} \\
\text { 86's korunmuștur. }\end{array}$ & & $\begin{array}{l}\text { Ballesteros } \\
\text { vd. (2017) }\end{array}$ \\
\hline $\begin{array}{l}\text { Böğ̈̈rtlen } \\
\text { (Rubus } \\
\text { fruticosus) } \\
\text { atıklar1 }\end{array}$ & $\begin{array}{l}\text { Antosiyanin } \\
\text { ve } \\
\text { antioksidan } \\
\text { bileşikler }\end{array}$ & $\begin{array}{lrr}\text { Elde edilen } & \text { parçacıklar } \\
\text { küresel bir } & \text { mikroyap1 } \\
\text { sergilemiştir. } & \end{array}$ & $\begin{array}{ll}\text { Elde edilen } & \text { parçacıklar } \\
\text { düzensiz } & \text { aglomeratlar } \\
\text { oluşturmuştur. } & \end{array}$ & $\begin{array}{lr}\text { Her iki yöntemle de } \\
\text { örneklerde } & \text { yüksek } \\
\text { antosiyanin } & \text { verimi } \\
\text { (\%76'nın üzerinde) ve } \\
\text { yüksek antioksidan kapasite } \\
\text { (1001 } \mu \text { mol } & \text { TE/g) elde } \\
\text { edilmiştir. } & \text { Kullanılan } \\
\text { kaplama } & \text { materyali } \\
\text { (polivinilpropilen) } \\
\text { antosiyaninleri hapsetmede } \\
\text { etkili olmuştur. }\end{array}$ & $\begin{array}{l}\text { Machado } \\
\text { vd. (2018) }\end{array}$ \\
\hline
\end{tabular}


Çizelge 1. devam

\begin{tabular}{|c|c|c|c|c|c|}
\hline Hammadde & $\begin{array}{l}\text { Hedef } \\
\text { bileşik/ürün }\end{array}$ & Püskürtmeli kurutma & Dondurarak kurutma & Ortak özellikler/faydalar & Kaynak \\
\hline $\begin{array}{l}\text { Acerola } \\
\text { (Malpighia } \\
\text { emarginata } \\
\text { DC.) } \\
\text { meyvesi } \\
\text { posas1 }\end{array}$ & $\begin{array}{l}\text { Biyoaktif } \\
\text { bileşikler }\end{array}$ & $\begin{array}{l}\text { Toz örnekler daha düşük } \\
\text { nem içeriği, aw, higroskopik } \\
\text { özellik, parçacık boyutu ve } \\
\text { yüksek çözünürlüğe sahip } \\
\text { olmuştur. Karotenoit, asetik } \\
\text { asit ve fenolik maddeler } \\
\text { açısından daha düşük } \\
\text { mikroenkapsülasyon } \\
\text { verimliliği elde edilmiştir. } \\
\text { Genel olarak, daha yüksek } \\
\text { biyoaktif } \\
\text { konsantrasyonu (asetik asit } \\
\text { hariç) ve daha yüksek } \\
\text { antioksidan } \\
\text { sağlanmışırtı. aktivite } \\
\end{array}$ & $\begin{array}{l}\text { Toz üründe } \\
\text { mikroenkapsülasyon etkinliği } \\
\text { daha yüksektir (\%78-97). } \\
\text { Kurutulmuş ürünler düzensiz } \\
\text { morfolojik yapiya sahip } \\
\text { olmuştur. }\end{array}$ & $\begin{array}{l}\text { Acerola atı̆̆ özütleri } \\
\text { acerola özütlerine göre } \\
\text { daha yüksek biyoaktif } \\
\text { bileşik konsantrasyonuna } \\
\text { (asetik asit hariç) ve daha } \\
\text { düşük antioksidan } \\
\text { aktiviteye sahiptir. }\end{array}$ & $\begin{array}{l}\text { Rezende } \\
\text { vd. (2018) }\end{array}$ \\
\hline Limon atığı & $\begin{array}{l}\text { Fenolik } \\
\text { bileşikler ve } \\
\text { flavonoit }\end{array}$ & $\begin{array}{l}\text { Farklı kaplama materyalleri } \\
\text { kullanılmış ve kaplama } \\
\text { materyallerinden bağımsız } \\
\text { olarak farklı boyutlarda } \\
\text { küresel } \\
\begin{array}{l}\text { oluşmuştur. parçacıklar } \\
\end{array}\end{array}$ & $\begin{array}{l}\text { Maltodekstrin ve soya } \\
\text { fasulyesi proteini karışımı ile } \\
\text { kapsüllenen tozlar en yüksek } \\
\text { fenolik }(1.66 \mathrm{mg} \mathrm{GAE} / \mathrm{g} \mathrm{kb}) \\
\text { ve flavonoit }(0.43 \mathrm{mg} \mathrm{KE} / \mathrm{g} \\
\mathrm{kb} \text { ) miktarına, düşük nem } \\
\text { içeriği ve } \mathrm{a}_{\mathrm{w}} \text { değerine sahip } \\
\text { olmuştur. }\end{array}$ & $\begin{array}{l}\mathrm{X} \text { 1şını kırınımı analizi } \\
\text { sonucu, her iki teknikle } \\
\text { üretilen örneklerde de } \\
\text { düşük kristallik derecesi } \\
\text { belirlenmiştir. }\end{array}$ & $\begin{array}{l}\text { Papoutsis } \\
\text { vd. (2018) }\end{array}$ \\
\hline Gül atığ1 & Antosiyanin & $\begin{array}{l}\text { Toz örnekler küresel bir yap1 } \\
\text { sergilemiş ve gül antosiyanin } \\
\text { özütlerine benzer } \\
\text { niteliklerde, arzu edilir renk } \\
\text { özellikleri sergilemiştir. }\end{array}$ & $\begin{array}{l}\text { Tozlar daha homojen } \\
\text { dağıllımlı ve katmanlı bir } \\
\text { yapiya sahiptir. Daha yüksek } \\
\text { fenolik (\%91.44) ve } \\
\text { antosiyanin } \quad(\% 95.12) \\
\text { tutunması tespit edilmiştir. } \\
\text { Depolama süresince daha } \\
\text { yüksek antosiyanin stabilitesi } \\
\text { bulgulanmıştır. }\end{array}$ & $\begin{array}{l}\text { Her iki kurutma işlemi de } \\
\text { gül atıkları için etkili bir } \\
\text { koruma sağlamış̧ır. Gül } \\
\text { atığından elde edilen } \\
\text { örnekler gül antosiyanin } \\
\text { özütlerine kıyasla daha } \\
\text { düšük nem içeriği, aw } \\
\text { değeri ve önemli ölçüde } \\
\text { daha yüksek çözünürlüğe } \\
\text { sahiptir. }\end{array}$ & $\begin{array}{l}\text { Yu ve Lv } \\
(2019)\end{array}$ \\
\hline $\begin{array}{l}\text { Üzüm } \\
\text { posas1 }\end{array}$ & $\begin{array}{l}\text { Biyoaktif } \\
\text { bileşikler }\end{array}$ & $\begin{array}{l}\text { Peyniraltı suyu ve gam arabik } \\
\text { karışımı ile fenolik bileşikler } \\
\text { en üst düzeyde }(2.66 \mathrm{mg} / \mathrm{g} \\
\text { GAE) tutunmuş ve en } \\
\text { yüksek DPPH antioksidan } \\
\text { kapasite değeri (12.64 } \\
\mu \text { mol/g TE) sağlanmışıtı. }\end{array}$ & $\begin{array}{l}\text { Peynir altı suyu ve gam arabik } \\
\text { karışımı ile kaplanan tozlar } \\
\text { daha yüksek toplam } \\
\text { monomerik antosiyanin }(0.35 \\
\text { mg/g malvidin-3,5-diglikozit } \\
\text { eşdeğeri) ve antioksidan } \\
\text { kapasite }(8.32 \mu \mathrm{mol} / \mathrm{g} \text { TE }) \\
\text { sağlamıştır. }\end{array}$ & $\begin{array}{l}\text { Peynir altı suyu ve gam } \\
\text { arabik karışımı ile } \\
\text { kaplanan tozlar simüle } \\
\text { bağırsak ortamında } \\
\text { antosiyaninlerin daha } \\
\text { yüksek oranda salınımını } \\
\text { sağlamıstır. }\end{array}$ & $\begin{array}{l}\text { Rocha ve } \\
\text { Noreña } \\
(2020)\end{array}$ \\
\hline
\end{tabular}

aw: Su aktivitesi; KE: Kateşin eşdeğeri; DPPH: 2,2-difenil-1-pikrilhidrazil; GAE: Gallik asit eşdeğeri; kb: Kuru bazda; TE: Troloks eşdeğeri.

Gıda maddelerinin kurutulması karmaşık bir işlemdir çünkü kurutma esnasında tozun fizikokimyasal özelliklerini etkileyen fiziksel, kimyasal ve biyokimyasal dönüşümler meydana gelebilmektedir. $\mathrm{Bu}$ nedenle kurutucu işlem koşulları besleme miktarına, üretilen ürüne, kurutmanın amacina ve kullanilan yöntemlere göre belirlenmelidir (Shishir ve Chen, 2017). Örneğin daha yüksek hava giriş/kurutma sıcaklığı, toz verimi ile kurutma hizinin artmasinı sağlamaktadır. Kurutma hızı aynı zamanda toz ürüne ait kütle yoğunluğu, nem içeriği, renk, parçacık boyutu, besin bileşenleri içeriği ve 1slanabilirlik özelliklerini etkilemektedir (Cai ve
Corke, 2000, Fazaeli vd., 2012). Bu bağlamda Laokuldilok ve Kanhaa (2015) siyah pirinç kepeğinden antosiyanin eldesinde hava giriş sıcaklığındaki artışla birlikte yığın yoğunluğu ve antosiyanin tutulmasında azalma, işlem verimliliği, çözünürlük, dağılabilirlik, akabilirlik özelliklerinde ise artış gözlemlemişlerdir. Salem vd. (2020) ise püskürtmeli kurutmanın köpekbalığ1 derisinden elde edilen jelatin tozlarının köpük ve emülsiyon özellikleri ile yağ bağlama ve su tutma kapasitelerini geliştirdiğini tespit etmişlerdir. Bununla birlikte, bazı araştırmacılar püskürtmeli kurutma işlemi ile daha düşük nem içeriği, higroskopik özellik ve su aktivite değeri (Kuck ve 
Noreña, 2016; Rezende vd., 2018) tespit ederken dondurarak kurutma işlemi ile daha düşük nem ve su aktivitesi değeri bildiren çalışmalar da mevcuttur (Papoutsis vd., 2018).

Gıda ürünlerinin kompleks yapısı ve özelliklerinin çeşitliliği nedeniyle tek bir kurutma tekniği, nihai ürünün kalite gereksinimlerini karşılamak için yetersiz kalabilmektedir. Örneğin, püskürtmeli kurutmanın termal bir işleme dayanıyor olması ve parçacıkların oksijen ile temas etmesi, sıcaklı̆ga ve oksidasyona karşı duyarlı bileşikler için dezavantaj oluşturabilmektedir (Ratti, 2013). Diğer yandan, dondurarak kurutma teknolojisinin vakum altında ve düşük sıcaklıklarda gerçekleşmesinin sıcaklığa duyarlı malzemelerin renk, aroma ve besin değerlerini yüksek oranda koruyabildiğini ifade eden çalışmalar mevcuttur (Ratti, 2001; Sun vd., 2019). Buna karşın Arsa ve Theerakulkait (2018), pirinç kepeğinden püskürtmeli ve dondurarak kurutma yöntemlerinin aroma bileşikleri üzerine etkilerini inceledikleri çalışmalarında püskürtmeli kurutma işlemi ile elde edilen üründe daha yüksek oranlarda arzu edilen aroma bileşikleri tespit etmişlerdir. Machado vd. (2018) ise hem püskürtmeli hem de dondurarak kurutma yöntemleri ile böğürtlen atıklarından elde edilen antosiyanin örneklerinin yüksek antosiyanin verimi ve antioksidan kapasite gösterdiğini bildirmişlerdir. Gıda bileşenlerini veya hücrelerini neme, 1sıya veya oksijene karşı korumak, uçuculuğu yüksek oranda önlemek ve aromay1 muhafaza etmek amaciyla kurutma parametrelerinin kontrolünün yanında mikroenpsülasyon gibi teknolojilerden de yaygin olarak faydalanılmaktadır (Fang ve Bhandari, 2011). Bu nedenle, çalışma sonuçlarında oluşan farklıliklar kullanilan kaplama materyalleri ile de ilişskilendirilebilir. Çizelge 1'deki bulgular incelendiğinde, farklı bileşenlerin mikroenkapsülasyona tabi tutulduğu işlemlerde fenolik bileşiklerin kapsüllenme verimi açısından dondurarak kurutma yönteminin daha etkili olduğu çalışmalar (Saikia vd., 2015; Ballesteros vd., 2017; Papoutsis vd., 2018) mevcutken püskürtmeli kurutma ile daha yüksek kapsülleme verimi elde edilen çalışmalar da (Rocha ve Noreña, 2020) mevcuttur. Bununla birlikte antosiyaninin kapsüllenme verimliliği için yine her iki kurutma yönteminin de avantajlı olduğu sonuçlar elde edilmiştir. Bu bağlamda Zang vd. (2020) püskürtmeli kurutma işlemini daha etkin olarak ifade ederken Murali vd. (2014) ve Laokuldilok ve Kanhaa (2015) ise dondurarak kurutma işleminde daha yüksek kapsüllenme verimi elde etmişlerdir. Tüm bu çalışmalardan yola çıkılarak mikroenkapsülasyon işlemi için kullanilan kaplama materyalinin hammaddeye, hedef bileşiklere ve kurutma yöntemine uygunluğu da önem arz etmektedir. Ek olarak kurutma işlemlerinin elde edilen toz ürünlerin mikroyapısını etkilediği de bilinmektedir. Püskürtmeli kurutma işleminde ürün damlacık formunda kurutulduğundan doğal olarak küresel partiküller elde edilmektedir. Buna karşın, dondurarak kurutulan örnekler ek bir öğütme işlemine tabi tutulduklarından küresel bir yapıya sahip değildirler. Genel olarak Çizelge 1'de yer alan literatür çalışmalarında da bu durumu destekler nitelikte püskürtmeli kurutma ile elde edilen tozların daha küresel bir mikroyap1 gösterdiği, dondurarak kurutulmuş örneklerde ise daha keskin kenarlı ve düzensiz parçacıklar elde edildiği rapor edilmiştir.

\section{SONUÇ VE ÖNERİLER}

Püskürtmeli kurutma, nihai ürünün partikül boyutu ve dağılımı, nem içeriği, yığın yoğunluğu ve morfoloji gibi özelliklerinde daha iyi kalitede tozlar üretmesi nedeniyle en çok tercih edilen kurutma yöntemlerinin başında gelmektedir. Püskürtmeli kurutmanın yüksek kalitede toz ürün sağlamasının yanında dondurarak kurutmaya kıyasla daha düşük enerji ihtiyacı ve sürekli çalışabilmesi, sağladığ1 diğer avantajları arasında öne çıkmaktadır. Buna karşın, yöntemin termal işleme dayanması, parçacıkların oksijen ile teması gibi durumlar bu yöntemin diş etkenlere karşı duyarlı gıda bileşenlerinin (protein, fenolik bileşikler, vitaminler, renk maddeleri vb.) bozulma veya kayılarnna neden olabilmektedir. $\mathrm{Bu}$ durumda düşük sıcaklıklarda ve vakum altında çalışmaya izin veren dondurarak kurutma yöntemi öne çıkmakta ve böylece sıcaklığa ve oksijene duyarlı bileşiklerin yüksek oranda korunumu sağlanabilmektedir. Kurulum maliyeti ve uzun işlem süresi ise dondurarak kurutma yönteminin en önemli dezavantajlarıdır. Buna ek olarak işlem 
sonunda ek bir öğütme işlemi gerektiriyor olması dondurarak kurutma işleminin kullanımını sınırlamaktadır. Buna karşın her iki kurutma tekniğinin oluşturabileceği olumsuzlukların önüne geçebilmek için mikroenkapsülasyon işlemi uygulanmaktadır. $\mathrm{Bu}$ sayede istenmeyen fiziksel değişikliklere (yapışma, kabuk bağlama, topaklanma vb.) neden olabilecek durumlarn yanında, kimyasal özelliklerdeki değişimlerin de önüne geçilebilmektedir. $\mathrm{Bu}$ noktada hammaddenin fiziksel, kimyasal ve mikrobiyolojik özellikleri ile kurutma ișlemlerinin son ürünün kalite özellikleri üzerindeki etkileri de göz önüne alınarak kullanılacak kurutma yöntemine karar verilmesi önem kazanmaktadır.

Günümüzde tüketicilerin kaliteli, güvenilir, ilave sentetik katk1 maddesi veya koruyucu madde içermeyen sağlıklı ve fonksiyonel gıdalara artan talebini karşılamak için ilgili sektörler çeşitli çalışmalar yapmaktadır. Bu noktada gıda atıklarından özütleme işlemleri sonucu elde edilen fonksiyonel bileşiklerden üretilen tozların önemi ortaya çıkmakta ve bu ürünlere olan taleplerin gelecek yillarda daha da artacağ1 tahmin edilmektedir. $\mathrm{Bu}$ derleme makale kapsamında potansiyel fonksiyonel bileşik kaynağı olan gida atıklarının püskürtmeli ve dondurarak kurutma teknikleri ile geri kazanımı, kurutucu sistem mekanizmaları ve uygulamaları tartışılmıştır. Mevcut çalışmanın gida işleme ve atık değerlendirme konularında çalışan profesyoneller ve araşturmacılar için yol gösterici bir kaynak olabileceği düşünülmektedir.

\section{ÇIKAR ÇATIŞMASI BEYANI}

Yazarların, başka kişiler ve/veya kurumlar ile çıkar çatışması bulunmamaktadır.

\section{YAZAR KATKILARI}

Tüm yazarlar yayının planlanması ve yazımında eşit oranda katkı sağlamışlardır.

\section{TEŞEKKÜR}

Yazarlar olarak, Türkiye Bilimsel ve Teknolojik Araştorma Kurumu'na (TÜBİTAK; Proje no: 217O066) teşekkürlerimizi sunarız.

\section{KAYNAKLAR}

Adhikari, B. Howes, T., Bhandari, B. R., Troung, V. (2003). Surface stickiness of drops of carbohydrate and organic acid solutions during convective drying: Experiments and modelling. Dry Technol, 21(5): 839-873, https://doi.org/ 10.1081/DRT-120021689.

Arsa, S., Theerakulkait, C. (2018). Preparation, aroma characteristics and volatile compounds of flavorings from enzymatic hydrolyzed rice bran protein concentrate. J Food Sci Agric, 98(12): 44794487; https://doi.org/10.1002/jsfa.8972.

Arshadi, M., Attard, T. M., Lukasik, R. M., Brnčić, M., Da Costa Lopes, A. M., Finell, m. et al. (2016). Pre-treatment and extraction techniques for recovery of added value compounds from wastes throughout the agrifood chain. Green Chem, 18(23): 6160-6204, https://doi.org/10.1039/C6GC01389A.

Assegehegn, G., Brito-de la Fuente, E., Franco, J. M., Gallegos, C. (2019). The importance of understanding the freezing step and its impact on freeze-drying process performance. J Pharm Sci, 108(4):

1378-1395, https://doi.org/10.1016/j.xphs.2018.11.039.

Ayadi, M. A., Khemakhem, M., Belgith, H., Attia, H. (2008). Effect of moderate spray drying conditions on functionality of dried egg white and whole egg. J Food Sci, 73: E281-E287, https://doi.org/10.1111/j.1750-

3841.2008.00811.x.

Ballesteros, L. F., Ramirez, M. J., Orrego, C. E., Teixeira, J. A., Mussatto, S. I. (2017). Encapsulation of antioxidant phenolic compounds extracted from spent coffee grounds by freeze-drying and spray-drying using different coating materials. Food Chem, 237: 623-631, https://doi.org/10.1016/j.foodchem.(2017).05.1 42.

Barbosa-Cánovas, G. V., Juliano, P. (2005). Physical and chemical properties of food powders. Encapsulated and Powdered Foods, 39 - 71.

Bataglion, G. A., Da Silva, F. M. A., Eberlin, M. N., Koolen H. H. F. (2015). Determination of the phenolic composition from Brazilian tropical fruits by UHPLC-MS/MS. Food Chem, 180: 280- 
287, https://doi.org/10.1016/j.foodchem. 2015.02.059.

Bhandari, B. (2013). Introduction to food powders, Handbook of food powders (Bhandari, B., chief ed..), Woodhead Publishing, Sawston, $\mathrm{p}$ 688.

Botrel, D. A., Barros Fernandes, R. V. D., Borges, S. V., Yoshida, M. I. (2014). Influence of wall matrix systems on the properties of spray-dried microparticles containing fish oil. Food Res Int, 62: 344-352, https://doi.org/10.1016/j.foodres. (2014).02.003.

Burgain, J., Petit, J., Scher, J., Rasch, R., Bhandari, B., Gaiani, C. (2017). Surface chemistry and microscopy of food powders, Prog Surf Sci, 92(4): 409-429, https://doi.org/10.1016/j.progsurf. (2017).07.002.

Cai, Y., ve Corke, H. (2000). Production and properties of spray-dried amaranthus betacyanin pigments. J Food Sci, 65: 1248e1252, https://doi.org/10.1111/j.1365-

2621.2000.tb10273.x.

Cal, K., ve Sollohub, K. (2010). Spray drying technique. I: Hardware and process parameters. $J$ Pharm Sci, 99: 575e586, https://doi.org/10.1002/jps.21886.

Cao, X., Zhang, F., Zhao, D., Zhu, D., Li, J. (2018). Effects of freezing conditions on quality changes in blueberries. J Sci Food Agric, 98(12): 4673-4679,https://doi.org/10.1002/jsfa.9000.

Calderón-Oliver, M., Pedroza-Islas, R., EscalonaBuendía, H. B., Pedraza-Chaverri, J., PonceAlquicira, E. (2017). Comparative study of the microencapsulation by complex coacervation of nisin in combination with an avocado antioxidant extract. Food Hydrocoll, 62: 49-57, https://doi.org/10.1016/j.foodhyd.(2016).07.02 8.

Can Karaca, A., Guzel, O., Ak, M. M. (2016). Effects of processing conditions and formulation on spray drying of sour cherry juice concentrate. J Sci Food Agric, 96: 449e455, https://doi.org/10.1002/jsfa.7110.

Caparino, O. A., Tang, J., Nindo, C. I., Sablani, S. S., Powers, J. R., ve Fellman, J. K. (2012). Effect of drying methods on the physical properties and microstructures of mango (Philippine "Carabao" var.) powder. J Food Eng, 111: 135e148, https://doi.org/10.1016/j.jfoodeng.2012.01.010.

Ceballos, A. M., Giraldo, G. I., Orrego, C. E. (2012). Effect of freezing rate on quality parameters of freeze dried soursop fruit pulp. $J$ Food Eng, 111(2): 360-365, https://doi.org/10.1016/j.jfoodeng.2012.02.010.

Champagne, C. P., Fustier, P. (2007). Microencapsulation for the improved delivery of bioactive compounds into foods. Curr Opin Biotechnol 18: 184-190, https://doi.org/ 10.1016/j.copbio.2007.03.001.

Chan, S. Y., Choo, W. S. (2013). Effect of extraction conditions on the yield and chemical properties of pectin from cocoa husks. Food Chem, 141(4): 3752-3758, https://doi.org/10.1016/ j.foodchem.2013.06.097.

Chegini, G. R., Ghobadian, B. (2005). Effect of Spray-Drying Conditions on Physical Properties of Orange Juice Powder. Dry Technol, 23: 657-668, https://doi.org/10.1081/DRT-200054161.

Chegini, G. R., Khazaei, J., Ghobadian, B., Goudarzi, A. M. (2008). Prediction of process and product parameters in an orange juice spray dryer using artificial neural networks. J. Food Eng. 84(4): 534-543, https://doi.org/10.1016/j.jfoodeng. 2007.06.007.

Chen, M. L., Ning, P., Jiao, Y., Xu, Z., \& Cheng, Y. H. (2021). Extraction of antioxidant peptides from rice dreg protein hydrolysate via an angling method. Food Chemistry, 337: 128069, https://doi.org/10.1016/j.foodchem.2020.12806 9.

Chindapan, N., Niamnuy, C., Devahastin, S. (2018). Physical properties, morphology and saltiness of salt particles as affected by spray drying conditions and potassium chloride substitution. Powder Technol., 326, 265-271, https://doi.org/10.1016/j.powtec.2017.12.014.

Chronakis, I. S., Triantafyllou, A. Ö., Öste, R. (2004). Solid-state characteristics and redispersible properties of powders formed by spray-drying and freeze-drying cereal dispersions 
of varying $(1 \rightarrow 3,1 \rightarrow 4)$ - $\beta$-glucan content. $J$ Cereal Sci, 40: 183-193, https://doi.org/10.1016/j.jcs.2004.03.004.

Chuah, L., Rashih, (2012). Optimization of spray drying process parameters of Piper betle L. (Sirih) leaves extract coated with maltodextrin. J Chem Pharm, 4(3): 1833-1841. 4, ID: 8315610.

Correia, R., Grace, M. H., Esposito, D., Lila, M. A. (2017). Wild blueberry polyphenol-protein food ingredients produced by three drying methods: Comparative physico-chemical properties, phytochemical content, and stability during storage. Food Chem, 340: 553-562, https://doi.org/10.1016/j.powtec.(2018).09.063.

Cuq, B., Rondet, E., Abecassis, J. (2011). Food powders engineering, between knowhow and science: Constraints, stakes and opportunities, Powder Technol, 208(2): 244-251, https://doi.org/10.1016/j.powtec.(2010).08.012.

Dalmoro, A., Barba, A. A., Lamberti, G., d'Amore, M. (2012). Intensifying the microencapsulation process: Ultrasonic atomization as an innovative approach. Eur J Pharm Biopharm, 80: 471e477, https://doi.org/10.1016/j.ejpb.2012.01.006.

De Leonardis, A., Macciola, V., Iorizzo, M., Lombardi, S. J., Lopez, F., \& Marconi, E. (2018). Effective assay for olive vinegar production from olive oil mill wastewaters. Food chemistry, 240, 437-440, https://doi.org/10.1016/j.foodchem. 2017.07.159.

Delgado, A. E., Rubiolo, A. C. (2005). Microstructural changes in strawberry after freezing and thawing processes. LebensmittelWiss. U.-Technol, 38(2): 135-142, https://doi.org/10.1016/j.lwt.2004.04.015.

Dhanalakshmi, K. Ghosal, S., Bhattacharya, S. (2011). Agglomeration of Food Powder and Applications. Crit Rev Food Sci Nutr, 51(5) : 432441; DOI: 10.1080/10408391003646270.

Donsì, G., Ferrari, G., Matteo, D. I. (2001). Utilization of combined processes in freezedrying of shrimps. Food Bioprod Process, 79 (3): 152159, DOI: $10.1205 / 096030801750425244$.
Đorđević, V., Balanč, B., Belščak-Cvitanović, A., Lević,S., Trifković, K., Kalušević, A., Kostić, I., Komes, D., Bugarski, B., Nedović, V. (2015). Trends in Encapsulation Technologies for Delivery of Food Bioactive Compounds. Food Eng Rev, 7: 452-490, https://doi.org/ 10.1007/s12393-014-9106-7.

Duan, X., Yang, X., Ren, G., Pang, Y., Liu, L., Liu, Y. (2016). Technical aspects in freeze-drying of foods. Dry Tech, 34(11): 1271-1285, https://doi.org/10.1080/07373937.2015.109954 5.

Elez Garofulić, I., Zorić, Z., Pedisić, S., DragovićUzelac, V. (2016). Optimization of sour cherry juice spray drying as affected by carrier material and temperature. Food Technol Biotech, 54(4), 441449 .

Ermiş, E., Karasu, E. N. (2020). Spray dryıng of de-oiled sunflower protein extracts: functional properties and characterization of the powder. Gida: J Food, 45 (1): 39-49, DOI: 10.15237/gida.GD19096.

Fang, Z. X., Bhandari, B. (2011). Effect of spray drying and storage on the stability of bayberry polyhenols. Food Chem, 129: 1139-1147, DOI: 10.1016/j.foodchem.2011.05.093.

Fazaeli, M., Emam-Djomeh, Z., Kalbasi Ashtari, A., Omid, M. (2012). Effect of spray drying conditions and feed composition on the physical properties of black mulberry juice powder. Food Bioprod Process, 90: 667e675, https://doi.org/10.1016/j.fbp.2012.04.006.

Fonte, P., Reis, S., Sarmento, B. (2016). Facts and evidences on the lyophilization of polymeric nanoparticles for drug delivery. J. Control. Release, 225: 75-86, https://doi.org/10.1016/j.jconrel. 2016.01.034.

Gaidhani, K. A., Harwalkar, M., Bhambere, D., Nirgude, P. S. (2015). Lyophilization/freeze drying-a review. World J Pharm Res, 4(8): 516-543.

Galanakis, C. M., Tornberg, E., Gekas, V. (2010). Clarification of high-added value products from olive mill wastewater. J Food Eng, 99: 190-197, https://doi.org/10.1016/j.jfoodeng.2010.02.018. 
Gharsallaoui, A., Roudaut, G., Chambin, O., Voilley, A. and Saurel, R. (2007). Applications of spray-drying in microencapsulation of food ingredients. Food Res Int, 40(9): 1107-1121, https://doi.org/10.1016/j.foodres.2007.07.004.

Goula, A. M., Adamopoulos, K. G. (2010). A new technique for spray drying orange juice concentrate. Innov Food Sci Emerg Technol, 11(2): 342-351, https://doi.org/10.1016/j.ifset. 2009.12.001.

Goula, A. M., Adamopoulos, K. G. (2003). Spray drying performance of a laboratory spray dryer for tomato powder preparation. Dry Technol, 21(7):1273-1289, DOI: 10.1081/DRT120023180 .

Goula, A. M., Adamopoulos, K. G., Kazakis, N. A. (2004). Influence of spray drying conditions on tomato powder properties. Dry Tecbnol, 22(5): 1129-1151, DOI: 10.1081/DRT-120038584.

Goula, A. M. (2017). Implications of nonequilibrium state glass transitions in spray-dried sugar-rich foods. In Non-Equilibrium States and Glass Transitions in Foods, Woodhead Publishing, Sawston, (Bhandari, B., chief ed.), pp. 253-282.

Gu, M., Fang, H., Gao, Y., Su,T., Niu, Y., Yu, L. (2020). Characterization of enzymatic modified soluble dietary fiber from tomato peels with high release of lycopene. Food Hydrocoll, 99: 105321, https://doi.org/10.1016/j.foodhyd.2019.105321.

Haggag, Y. A., Faheem, A. M. (2015). Evaluation of nano spray drying as a method for drying and formulation of therapeutic peptides and proteins. Front Pharmacol, 6, 140.

Haque, M. A., Timilsena, Y. P., Adhikari, B. (2015). Spray drying. Drying Technologies for Foods: Fundamentals ve Applications New India Publishing Agency, India, (Nema, P. K., chief ed..), pp.79-106.

Hashtjin, A. M., Abbasi, S. (2015). Nanoemulsification of orange peel essential oil using sonication and native gums. Food Hydrocoll, 44: 4048, https://doi.org/10.1016/j.foodhyd. 2014.08.017.
Herrero M., Sánchez-Camargo, A. P., Cifuentes, A., Ibáñez, E. (2015). Plants, seaweeds, microalgae and food by-products as natural sources of functional ingredients obtained using pressurized liquid extraction and supercritical fluid extraction. Trends Analyt Chem, 71: 26-38, https://doi.org/10.1016/j.trac.2015.01.018.

Hua, M., Lu, J., Qu, D., Liu, C., Zhang, L., Li, S., Chen, J., Sun, Y. (2019). Structure, physicochemical properties and adsorption function of insoluble dietary fiber from ginseng residue: A potential functional ingredient. Food Chem, 286: 522-529, https://doi.org/10.1016/ j.foodchem.2019.01.114.

Intipunya, P., Bhandari, B. R. (2010). Chemical deterioration and physical instability of food and beverages. Handbook on Spray Drying Applications for Food Industries, Woodhead Publishing, , Sawston, (Skibsted, L., chief ed.), pp.663-700.

Jafari, S. M., Ghalenoei, M. G., Dehnad, D. (2017). Influence of spray drying on water solubility index, apparent density, and anthocyanin content of pomegranate juice powder. Powder Technol, 311: 59-65, https://doi.org/10.1016/j.powtec.2017.01.070.

Kalogeropoulos, N., Chiou, A., Pyriochou, V., Peristeraki, A., Karathanos, V. T. (2012). Bioactive phytochemicals in industrial tomatoes and their processing byproducts. LWT - Food Sci Technol, 49(2): 213-216, https://doi.org/10.1016/ j.lwt.2011.12.036.

Kawasaki, H., Shimanouchi, T., Kimura, Y. (2019). Recent development of optimization of lyophilization process. J Chem, 2019, https://doi.org/10.1155/2019/9502856.

Keshani, S., Daud, W. R. W., Nourouzi, M. M., Namvar, F., Ghasemi, M. (2015). Spray drying: An overview on wall deposition, process and modeling. J Food Eng, 146: 152-162, https://doi.org/10.1016/j.jfoodeng.2014.09.004.

Kuck, L. S., Noreña, C. P. Z. (2016). Microencapsulation of grape (Vitis labrusca var. Bordo) skin phenolic extract using gum Arabic, polydextrose, and partially hydrolyzed guar gum as encapsulating agents. Food Chem, 194: 569-576. 
https://doi.org/10.1016/j.foodchem.(2015).08.0 66.

Kumar, G., Prashanth, N., Kumari, B. (2011). Fundamentals and applications of lyophilization. J Adv Pharm Res, 2(4): 157-169.

Laokuldilok, T., Kanha, N. (2015). Effects of processing conditions on powder properties of black glutinous rice (Oryza sativa L.) bran anthocyanins produced by spray drying and freeze drying. LWT - Food Sci Technol, 64(1): 405-411. https://doi.org/10.1016/j.lwt.(2015).05.015.

León-Martínez, F. M., Méndez-Lagunas, L. L., Rodríguez-Ramírez, J. (2010). Spray drying of nopal mucilage (Opuntia ficus-indica): Effects on powder properties and characterization. Carbohydr Polym, 81(4): 864-870, https://doi.org/10.1016/ j.carbpol.2010.03.061.

Lin, C. S. K., Pfaltzgraff, L. A., Herrero-Davila, L., Mubofu, E. B., Abderrahim, S., Clark, J. H., Koutinas, A. A., Kopsahelis, N., Stamatelatou, K., Dickson, F., et al. (2013). Food waste as a valuable resource for the production of chemicals, materials and fuels. Current situation and global perspective. Energy Environ Sci, 6, 426-464, https://doi.org/10.1039/C2EE23440H.

Looi, Y. F., Ong, S. P., Julkifle, A., Alias, M. S. (2019). Effects of pretreatment and spray drying on the physicochemical properties and probiotics viability of Moringa (Moringa oleifera Lam) leaf juice powder. J Food Process Preserv, 43(4): e13915, https://doi.org/10.1111/jfpp.13915.

Luque, R., Clark, H. J. (2013). Valorisation of food residues: Waste to wealth using green chemical Technologies. Sustain Chem Process, 1, 1012, https://doi.org/10.1186/2043-7129-1-10.

Maa, Y. F., Costantino, H., Nguyen, P. A., ve Hsu, C. (1997). The effect of operating and formulation variables on the morphology of spray dried protein particles. Pharm Dev Technol, 2: 213e223, https://doi.org/10.3109/ 10837459709031441.

Machado, A. P. D., Rezende, C. A., Rodrigues, R. A., Barbero, G. F., Rosa, P. D. V. E., Martinez, J. (2018). Encapsulation of anthocyanin-rich extract from blackberry residues by spray-drying, freeze- drying and supercritical antisolvent. Powder Technol, 340: 553-562, https://doi.org/10.1016/ j.powtec.(2018).09.063.

Makris, D. P., Boskou, G., Andrikopoulos, N. K. (2007). Polyphenolic content and in vitro antioxidant characteristics of wine industry and other agri-food solid waste extracts. J Food Compos Anal, 20(2): 125-132, https://doi.org/ 10.1016/j.jfca.2006.04.010.

Malamatari, M., Charisi, A., Malamataris, S., Kachrimanis, K., Nikolakakis, I. (2020). Spray drying for the preparation of nanoparticle-based drug formulations as dry powders for inhalation. Processes, 8(7), 788, https://doi.org/ $10.3390 /$ pr8070788.

Marques L. G., Freire, J. T. (2005). Analysis of freeze-drying of tropical fruits. Drying Technol, 23(9-11): 2169-2184, https://doi.org/10.1080/ 07373930500212438.

Marques, G. R., Borges, S. V., Mendonça, K. S. D., Fernandes, R. V. B., Menezesab, E. G. T. (2014). Application of maltodextrin in green corn extract powder production. Powder Technol, 263: 89-95, https://doi.org/10.1016/j.powtec. 2014.05.001.

Menon, A., Stojceska, V., Tassou, S. A. (2020). A systematic review on the recent advances of the energy efficiency improvements in nonconventional food drying technologies. Trends in Food Sci Tech, 100: 67-76, https://doi.org/ 10.1016/j.tifs.2020.03.014.

Miller, D. A., Gil, M. (2012). Spray-drying technology. In: Formulating Poorly Water Soluble Drugs, AAPS Advances in the Pharmaceutical Sciences Series, Robert O. W., Alan B. W., Dave A. M. (ed.), Springer, New York, pp. 363-442.

Mirabella N., Castellani V., Sala, S. (2014). Current options for the valorization of food manufacturing waste: a review. J Clean Prod, 65: 28-41, https://doi.org/10.1016/j.jclepro. 2013.10.051.

Morgan CA, Herman N, White PA, Vesey G. (2006). Preservation of micro-organisms by drying; a review. J Microbiol Methods, 66(2): 183-19, https://doi.org/10.1016/j.mimet.2006.02.017. 
Moses, J. A., Norton, T., Alagusundaram, K., Tiwari, B. K. (2014). Novel drying techniques for the food industry. Food Eng Rev, 6(3): 43-55, DOI 10.1007/s12393-014-9078-7.

Munekata, P. E. S., Franco, D., Trindade, M. A., Lorenzo, J. M. (2016). Characterization of phenolic composition in chestnut leaves and beer residue by LC-DAD-ESI-MS. LW'T - Food SciTechnol, 68: 52-58, https://doi.org/10.1016/ j.lwt.2015.11.017.

Murador, D. C., Braga, A. R. C., Martins, P. L., Mercadante, A. Z., \& de Rosso, V. V. (2019). Ionic liquid associated with ultrasonic-assisted extraction: A new approach to obtain carotenoids from orange peel. Food research international, 126: 108653, https://doi.org/10.1016/j.foodres. 2019.108653 .

Murali, S., Kar, A., Mohapatra, D., Kalia, P. (2014). Encapsulation of black carrot juice using spray and freeze drying. Food Sci Technol Int, 21(8); https://doi.org/10.1177/1082013214557843.

Muzaffer, K., Kumar, P. (2015). Parameter optimization for spray drying of tamarind pulp using responsesurface methodology. Powder Technol, 279: 179-184, https://doi.org/10.1016/ j.powtec.2015.04.010.

Neacsua, 1. M., Vaughana, N., Raikosa, V., Multaria, S., Duncanb, G. J., Duthiea, G. G., Russella, G. W. (2015). Phytochemical profile of commercially available food plant powders: their potential role in healthier food reformulations. Food Chem, 179: 159-169, https://doi.org/ 10.1016/j.foodchem.2015.01.128.

Nindo, C. I., Tang, J., (2007). Refractance Window dehydration technology: a novel contact drying method. Dry Technol, 25: 37-48, https://doi.org/10.1080/07373930601152673.

Nireesha, G. R., Divya, L., Sowmya, C., Venkateshan, N. N. B. M., Lavakumar, V. (2013). Lyophilization/freeze drying-an review. Int $J$ Novel Trends Pharm Sci, 3(4): 87-98, https://scienztech.org/ijntps/article/view/96.

Nuzzo, M., Millqvist-Fureby, A., Sloth, J., Bergenstahl, B. (2015). Surface composition and morphology of particles dried individually and by spray drying. Dry Technol, 33(6), 757-767.

Oliveira, T. I. S., Rosa, M. F., Cavalcante, F. L., Pereira, P. H. F., Moates, G. K., Wellner, N., Azeredo, H. M. C. (2016). Optimization of pectin extraction from banana peels with citric acid by using response surface methodology. Food Chem, 198: 113-118, https://doi.org/10.1016/ j.foodchem.2015.08.080.

Oreopoulou, V., Tzia, C. (2007). Utilization of plant by-products for the recovery of proteins, dietary fibers, antioxidants, and colorants, Utilization of by-products and treatment of waste in the food industry. Science and Business Media, (Oreopoulou, V. chief ed.), 209-232.

Papoutsis, K., Golding, C. B., Vuong, Q., Pristijono, P., Stathopoulos, C. E., Scarlett, C. J., Bowyer, M. (2018). Encapsulation of Citrus ByProduct Extracts by Spray-Drying and FreezeDrying Using Combinations of Maltodextrin with Soybean Protein and i-Carrageenan. Foods, 7(7): 115; https://doi.org/10.3390/foods 7070115.

Pereira, P. H. F., Oliveira, T. I. S., Rosa, M. F., Cavalcante, F. L., Moates, G. K., Wellner, N., Azeredo, H. M. C. (2016). Pectin extraction from pomegranate peels with citric acid. Int J Biol Macromol, 88: 373-379, https://doi.org/ 10.1016/j.ijbiomac.2016.03.074.

Pereira, R. M., López, B. G. C., Diniz, S. N., Antunes, A. A., Garcia, D. M., Oliveira, C. R., \& Marcucci, M. C. (2017). Quantification of flavonoids in Brazilian orange peels and industrial orange juice processing wastes. Agricultural Sciences, 8(07): 631, Doi: 10.4236/as.2017.87048.

Phisut, N. (2012). Spray drying technique of fruit juice powder: Some factors influencing the properties of product. Int Food Res J, 19: 12971306.

Pikal, M. J. (2002). Freeze drying. In Encyclopedia of Pharmaceutical Technology, Marcel Dekker, New York (2002), pp. 1299-1326.

Pisano, R., Barresi A. A., Fissore, D. 2011 Innovation in monitoring food freeze drying. Dry Technol, 29 (16): 1920-1931, https://doi.org/10.1080/07373937.2011.596299. 
Prinn, K. B., Costantino, H. R., Tracy, M. (2002). Statistical Modeling of protein spray drying at the lab scale. AAPS PharmSciTech, 3: 32-39, https://doi.org/10.1208/pt030104.

Putnik, P., Bursać Kovacević, D., Režek Jambrak, A., Barba, F. J., Cravotto, G., Binello, A., Shpigelman, A. (2017). Innovative "green" and novel strategies for the extraction of bioactive added value compounds from citruswastes. Molecules, 22(5), https://doi.org/10.3390/ molecules22050680.

Ratti, C. (2001). Hot air and freeze-drying of highvalue foods: A review. J Food Eng, 49 (4): 311-319, https://doi.org/10.1016/S0260-8774(00)002284.

Ratti, C. (2013). Freeze drying for food powder production. Handbook of Food Powders Woodhead Publishing Series in Food Science, Technology and Nutrition, (Bhandari, B., chief ed.), Sawston, pp. 57-84.

Rezende, Y. R. R. S., Nogueira, J. P., Narain, N. (2018). Microencapsulation of extracts of bioactive compounds obtained from acerola (Malpighia emarginata DC) pulp and residue by spray and freeze drying: Chemical, morphological and chemometric characterization. Food Chem, 254: 281-291, https://doi.org/10.1016/ j.foodchem.2018.02.026.

Rocha, C. B. D., Noreña, C. P. Z. (2020). Microencapsulation and controlled release of bioactive compounds from grape pomace. Dry Technol, 1-15, DOI: $10.1080 / 07373937$. (2020).1741004.

Rodríguez, R., Jiménez, A., Fernández-Bolaños, J., Guillén, R., Heredia. A. (2006). Dietary fibre from vegetable products as source of functional ingredients. Trends Food Sci Technol, 17, 3-15, https://doi.org/10.1016/j.tifs.2005.10.002.

Saikia, S., Mahnot, N. K., Mahanta, C. L. (2015). Optimisation of phenolic extraction from Averrhoa carambola pomace by response surface methodology and its microencapsulation by spray and freeze drying. Food Chem, 171: 144-152, https://doi.org/10.1016/j.foodchem.(2014).08.0 64.
Salem, A., Fakhfakh, N., Jridi, M., Abdelhedi, O., Nasri, M., Debeaufort, F., Zouari, N. (2020). Microstructure and characteristic properties of dogfish skin gelatin gels prepared by freeze/spray-drying methods. Int J Biol Macromol, 162:

$1-10$ https://doi.org/10.1016/j.ijbiomac.(2020).06.03 3.

Schössler, K., Jäger, H., Knorr, D. (2012). Novel contact ultrasound system for the accelerated freeze-drying of vegetables. Innov Food Sci Emerg Technol, 16: 113-120, https://doi.org/10.1016/j.ifset.2012.05.010.

Searles, J. A., Aravapalli, S., Hodge, C. (2017). Effects of chamber pressure and partial pressure of water vapor on secondary drying in lyophilization. AAPS PharmSciTech, 18(7): 28082813, https://doi.org/10.1208/s12249-0170768-3.

Shishir, M. R. I., Chen, W. (2017). Trends of spray drying: A critical review on drying of fruit and vegetable juices. Trends Food Sci Technol, 65: 49-67. https://doi.org/10.1016/j.tifs.(2017).05.006.

Souza, A. S., Borges, S. V., Magalhães, N. F., Ricardo, H. V., Cereda, M. P., Daiuto, E. R. (2009). Influence of spray drying conditions on the physical properties of dried pulp tomato. Food Sci Technol, 29(2): 291-294, https://doi.org/10.1590/S010120612009000200008.

Sun, Q., Zhang, M.,Mujumdar, A. S. (2019). Recent developments of artificial intelligence in drying of fresh food: A review. Food Sci Nutr, 59(14): 2258-2275, https://doi.org/10.1080/ 10408398.2018.1446900.

Sun, X., Cameron, R. G., Bai, J. (2020). Effect of spray-drying temperature on physicochemical, antioxidant and antimicrobial properties of pectin/sodium alginate microencapsulated carvacrol. Food Hydrocoll, 100: 105420, https://doi.org/10.1016/j.foodhyd.2019.105420.

Telang, A. M., Thorat, B. N. (2010). Optimization of process parameters for spray drying of fermented soy milk. Dry Technol, 28 (12): $1445-$ 1456, https://doi.org/10.1080/07373937. 2010.482694 . 
Toledo, R., (2007). Fundamentals of Food Process Engineering, (Heldman, D. R. Chief ed.), 3rd ed. Aspen Publishers, Inc., Athens, GA, ISBN: 978-3-319-90097-1.

Tontul, İ., Topuz, A. (2017). Spray-drying of fruit and vegetable juices: Effect of drying conditions on the product yield and physical properties. Trends Food Sci Technol, 63: 91-102, https://doi.org/10.1016/j.tifs.2017.03.009.

Tsouko, E., Alexandri, M., Fernandes, K. V., Guimarães Freire, D. M., Mallouchos, A., Koutinas, A. A. (2019). Extraction of Phenolic Compounds from Palm Oil Processing Residues and Their Application as Antioxidants. Food Technol Biotechnol, 57(1): 29-38, https://doi.org/10.17113/ftb.57.01.19.5784.

Venturi, F., Sanmartin, C., Taglieri, I., Nari, A., Andrich, G., Terzuoli, E., ... \& Zinnai, A. (2017). Development of phenol-enriched olive oil with phenolic compounds extracted from wastewater produced by physical refining. Nutrients, 9(8): 916, https://doi.org/10.3390/nu9080916.

Vidović, S. S., Vladić, J. Z., Vaštag, Z. G., Zeković, Z. P., Popović, L. M. (2014). Maltodextrin as a carrier of health benefit compounds in Satureja montana dry powder extract obtained by spray drying technique. Powder Technol, 258: 209-215, https://doi.org/10.1016/ j.powtec.2014.03.038.

Voda, A., Homan, N., Witek, M., Duijster, A., Van Dalen, G., Van der Sman, R., et al. (2012). The impact of freeze-drying on microstructure and rehydration properties of carrot. Food Res Int, 49(2): 687-693, https://doi.org/10.1016/ j.foodres.2012.08.019.

Yan, J. K., Wu, L. X., Cai, W. D., Xiao, G. S., Duan, Y., \& Zhang, H. (2019). Subcritical water extraction-based methods affect the physicochemical and functional properties of soluble dietary fibers from wheat bran. Food chemistry, 298, 124987, https://doi.org/ 10.1016/j.foodchem.2019.124987.

Yerlikaya, S., Şen Arslan, H. (2019). Dondurularak ve püskürterek kurutulmuş süt tozlarının bazı mikrobiyolojik ve fizikokimyasal
Özelliklerinin karşılaştırılması. Bitlis Eren Univ J Sci \& Technol, 8(2): 677 - 687, https://doi.org/10.17798/bitlisfen.511313.

Y1lmaz F. M., Görgüç A., Gençdağ E. (2021). Recovery and Purification of Antioxidant Compounds from Plant Origin Agro-Industrial By-products. In: Ekiert H. M., Ramawat K. G., Arora J. (eds.) Plant Antioxidants and Health. Reference Series in Phytochemistry. Springer, Cham. https://doi.org/10.1007/978-3-03045299-5_24-2.

Yu, Y., Lv, Y. (2019). Degradation kinetic of anthocyanins from rose (Rosa rugosa) as prepared by microencapsulation in freeze-drying and spraydrying. International Int. J. Food Prop 22(1): 2009 2021; https://doi.org/10.1080/10942912.(2019). 1701011.

Zaky, A. A., Abd El-Aty, A. M., Ma, A., \& Jia, Y. (2020). An overview on antioxidant peptides from rice bran proteins: extraction, identification, and applications. Critical Reviews in Food Science and Nutrition, 1-13, https://doi.org/10.1080/ 10408398.2020.1842324.

Zhang, R., Zhou, L., Li, J., Oliveira, H., Yang, N., Jin, W., Zhu, Z., Li, S., He, J. (2020). Microencapsulation of anthocyanins extracted from grape skin by emulsification/internal gelation followed by spray/freeze-drying techniques: Characterization, stability and bioaccessibility. LW'T - Food Sci Tech, 123: 109097 , https://doi.org/10.1016/j.lwt.(2020).109097.

Zhu, Z. J. He, J., Liu, G., Barba, F. J., Koubaa, M., Ding, L. et al.. (2016). Recent insights for the green recovery of inulin from plant food materials using non-conventional extraction technologies: A review. Innov Food Sci Emerg Tech, 3: 1-9, DOI: 10.1016/j.ifset.2015.12.023.

Ziaee, A., Albadarin, A. B., Padrela, L., Femmer, T., O'Reilly, E., Walker, G. (2019). Spray drying of pharmaceuticals and biopharmaceuticals: Critical parameters and experimental process optimization approaches. Eur. J. Pharm. Sci, 127: 300-318, https://doi.org/10.1016/j.ejps. 2018.10.02. 